
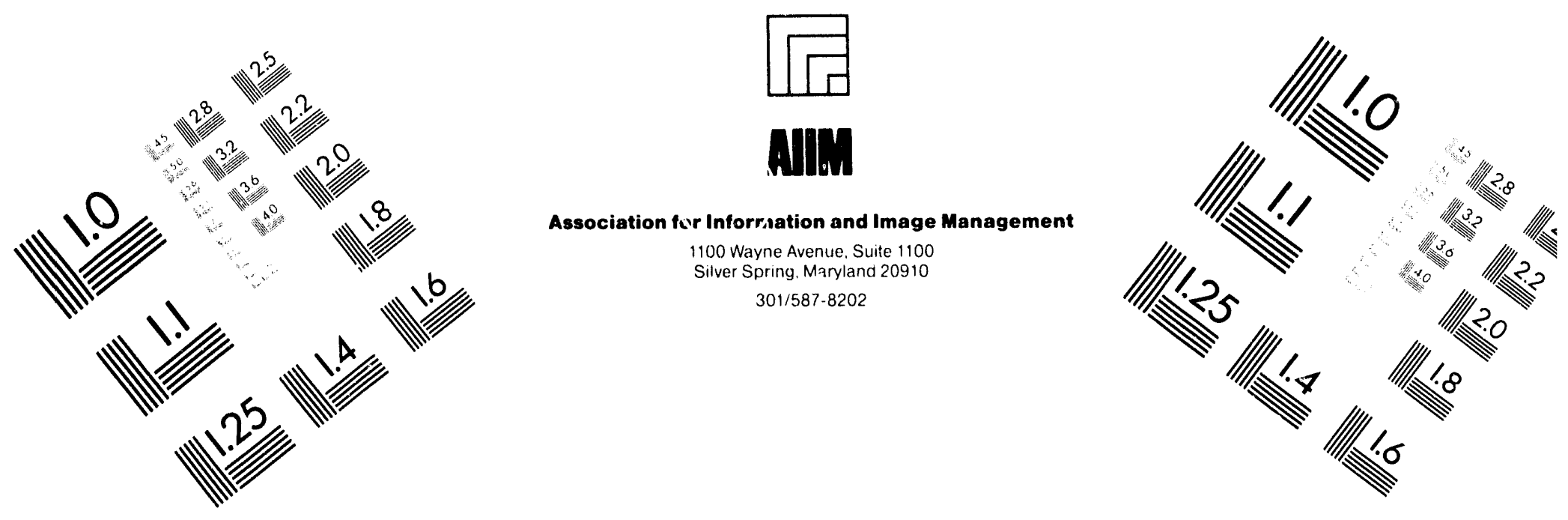

\title{
Centimeter
}

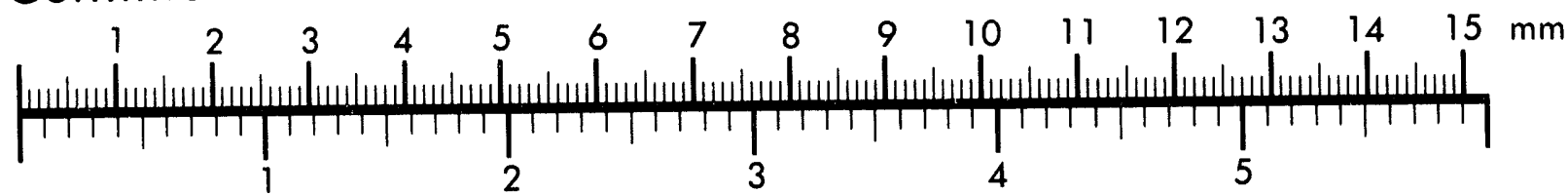

Inches
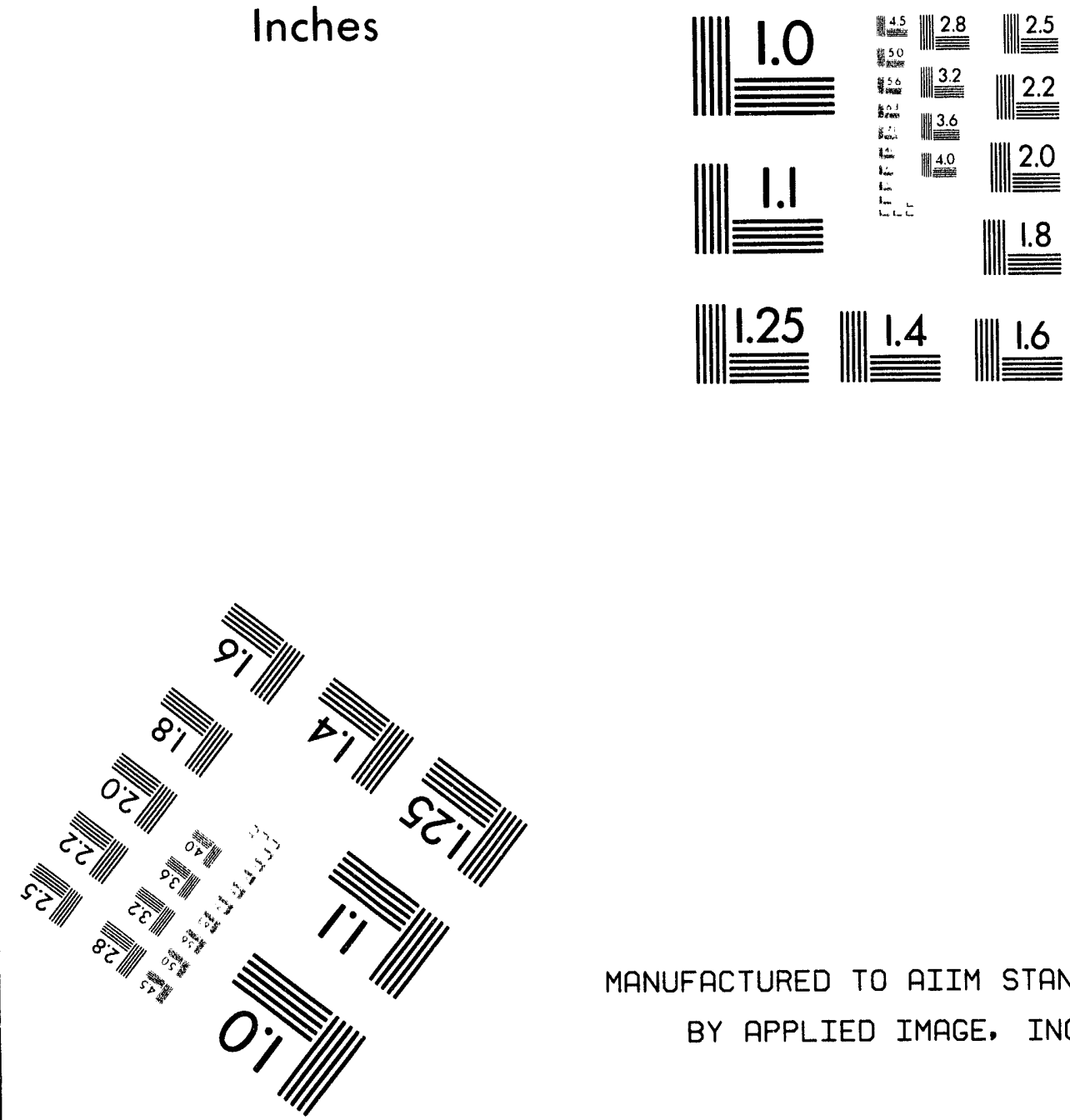

MANUFACTURED TO AIIM STANDARDS

BY APPLIED IMAGE, INC.

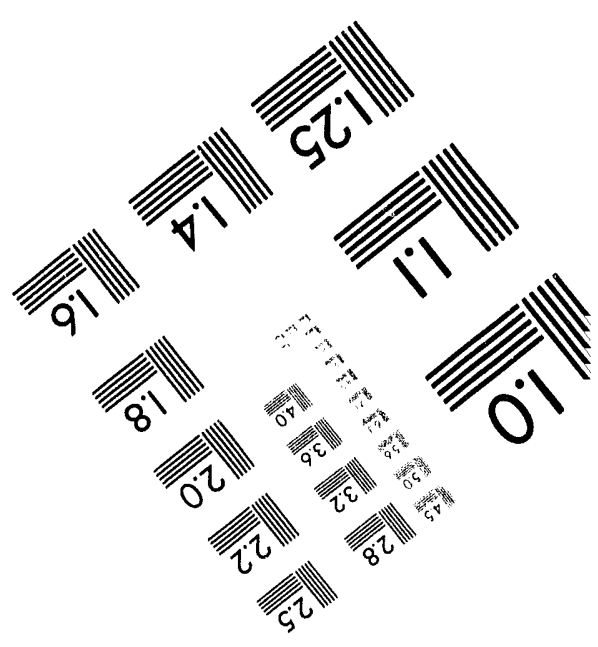



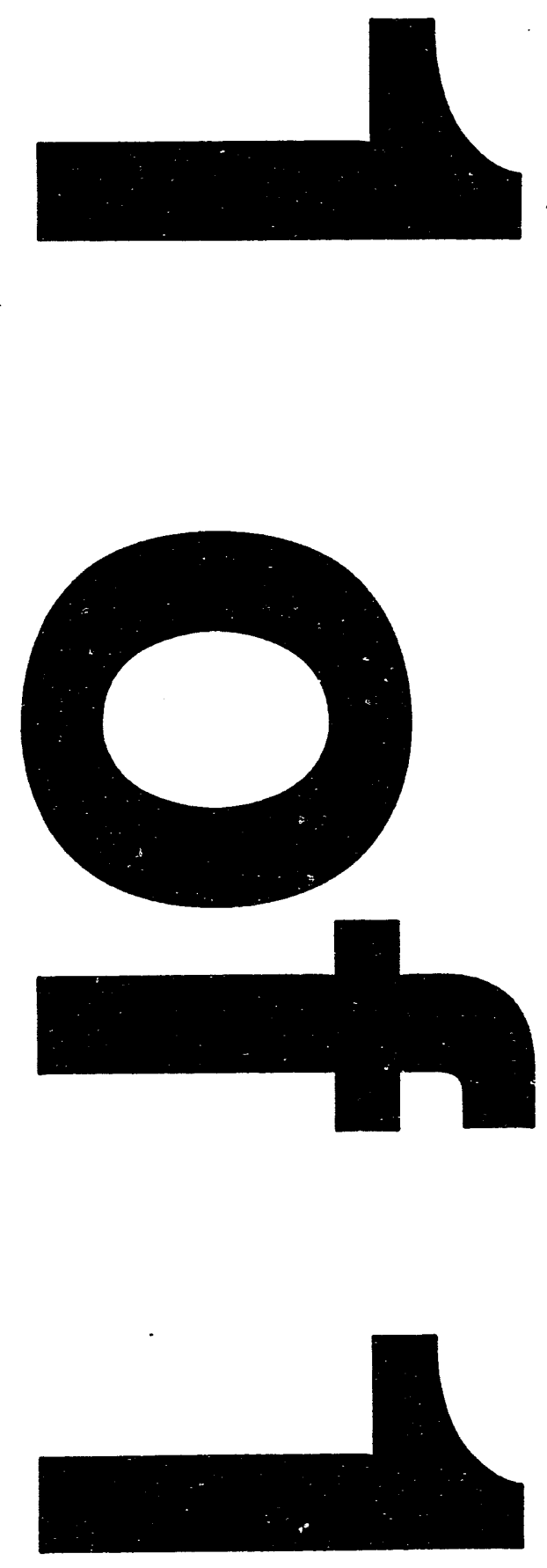


\section{Species Status of \\ Mill Creek Elliptio}

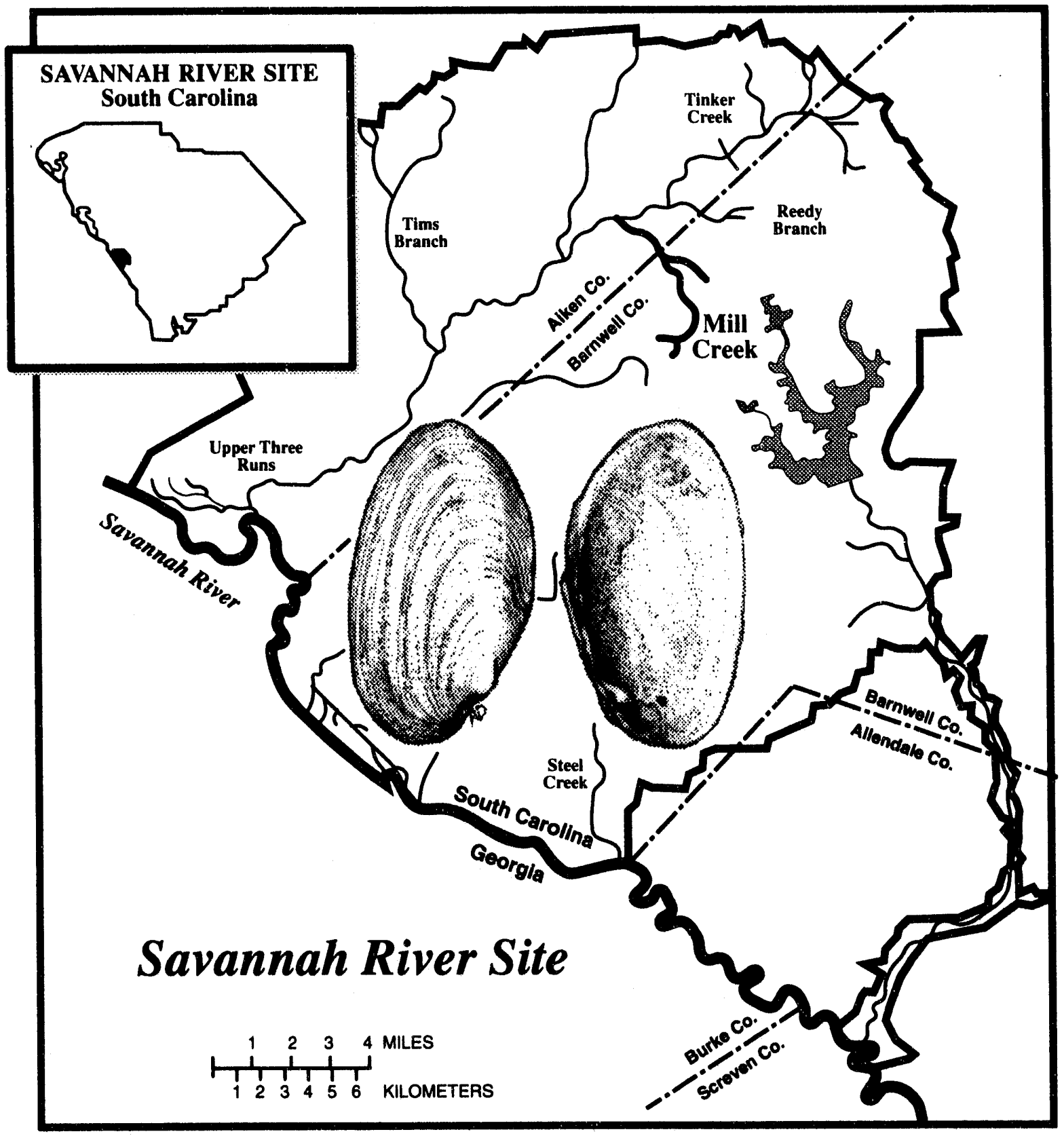

by

George M. Davis

Margaret Mulvey

A Publication of the Savannah River Site

National Environmental Research Park Program

1993 


\section{A PUBLICATION OF DOE'S SAVANNAH RIVER SITE NATIONAL ENVIRONMENTAL RESEARCH PARK}

\section{DECEMBER 1993}

This report was prepared as an account of work sponsored by the United States Government. Neither the United States nor the United States Department of Energy, nor any of their contractors, subcontractors, or their employees, makes any warranty, express or implied or assumes any legal liability or responsibility for the accuracy, completeness or usefulness of any information, apparatus, product or process disclosed, or represents that its use would not infringe privately owned rights.

Copies may be obtained from:

Savannah River Ecology Laboratory

Drawer E

Aiken, SC 29802

USA 


\title{
SPECIES STATUS OF MILL CREEK ELLIPTIO
}

\author{
George M. Davis \\ The Academy of Natural Sciences \\ Margaret Mulvey \\ Savannah River Ecology Laboratory
}

A Publication of the Savannah River Site

National Environmental Research Park Program

1993 


\section{TABLE OF CONTENTS}

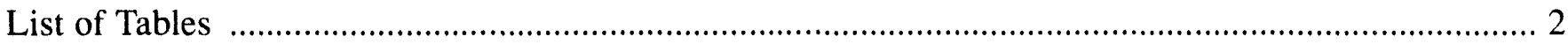

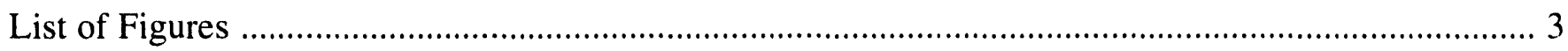

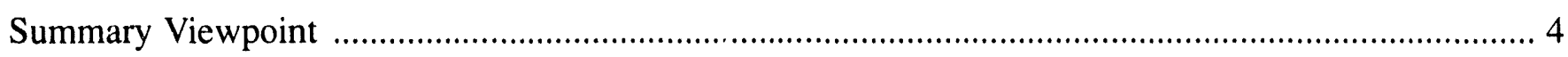

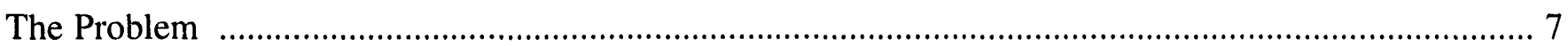

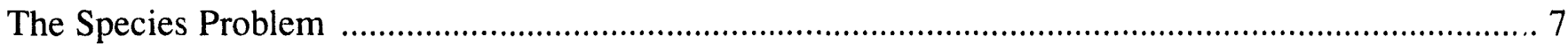

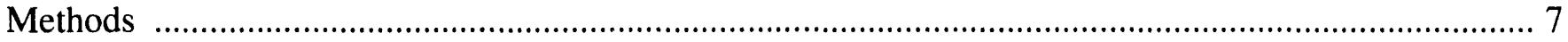

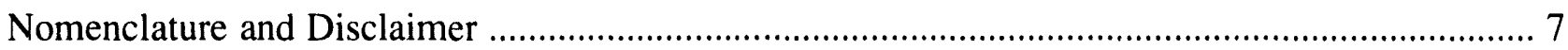

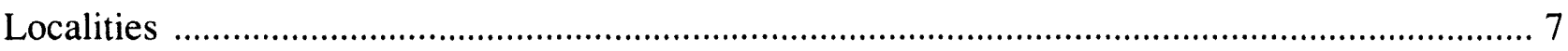

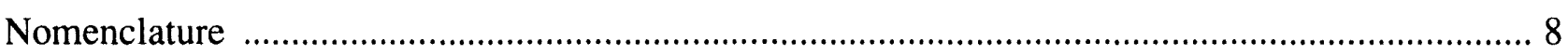

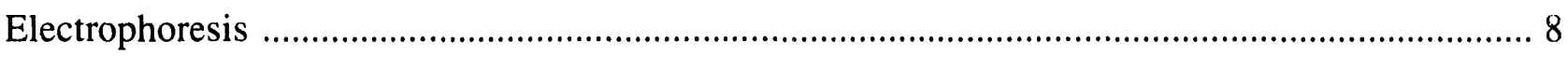

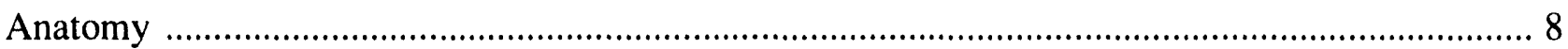

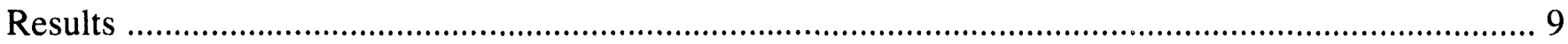

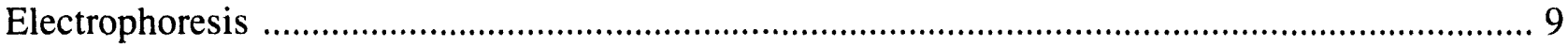

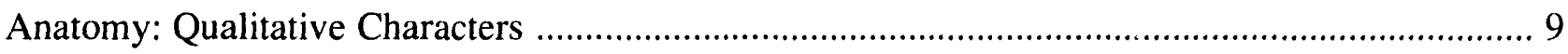

Anatomy: Quantitative Characters ................................................................................ 10

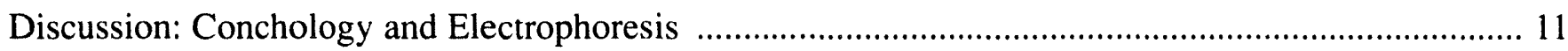

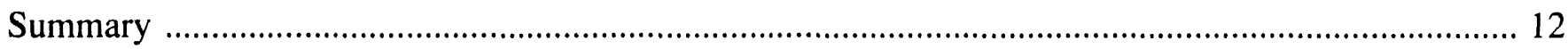

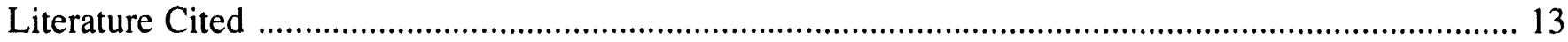

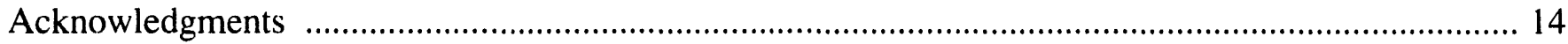

Appendices

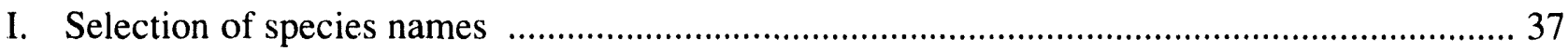

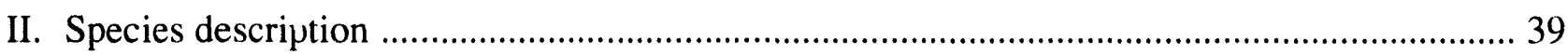




\section{LIST OF TABLES}

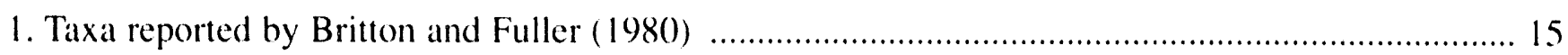

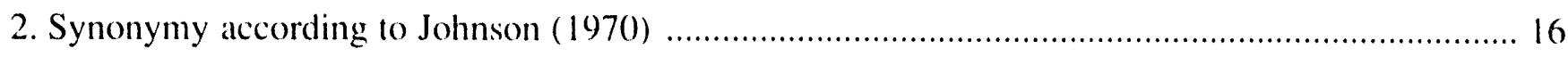

3. Distribution of nominal species among the seven collection sites ..................................................17

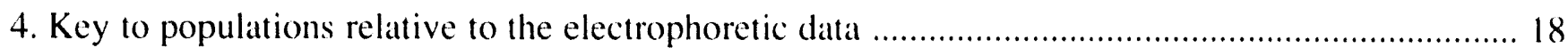

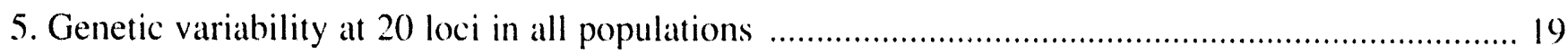

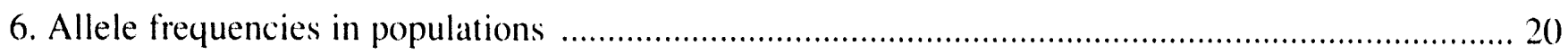

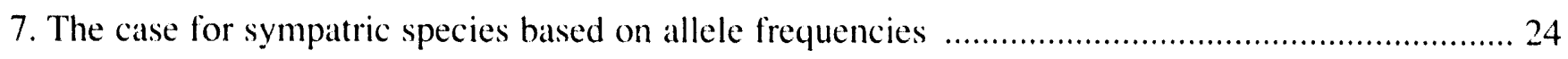

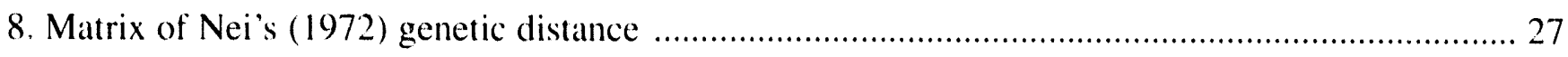

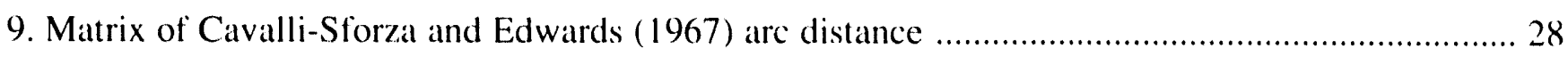

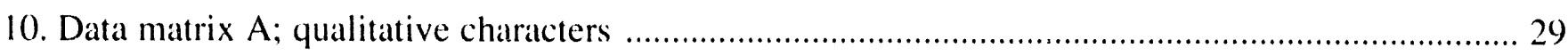

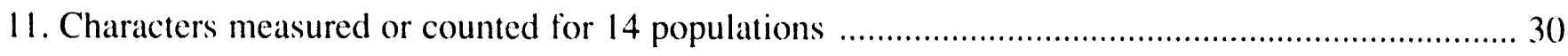

12. Qualitative anatomical characters: loadings for five principle components ..................................... 31

13. Qualitative anatomical characters: character loadings for the first five PCs ................................... 32

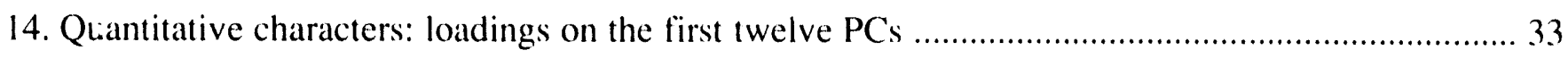

15. Character loading for the first five PCs involving quantitative anatomical data .............................. 34

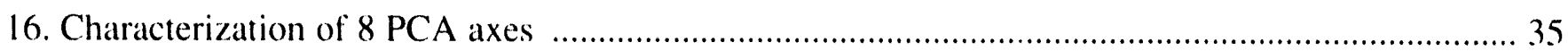




\section{LIST OF FIGURES}

1. Collection locations and major drainages of the Savannah River Site .................................. 41

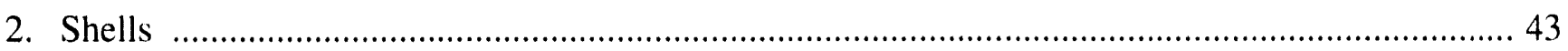

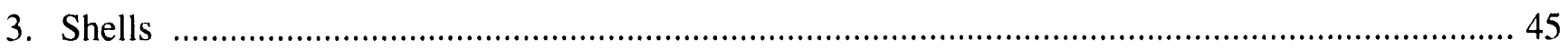

4. Phenogram of electrophoretic data using Nei genetic distance and UPGMA. ..........................46

5. Phenogram of electrophoretic data using Cavalli-Sforza arc distance and UPGMA ................. 47

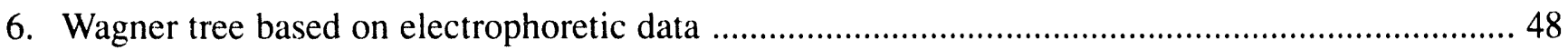

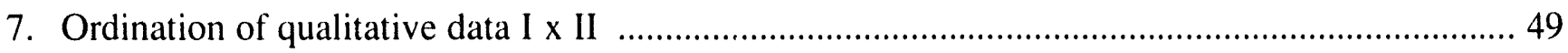

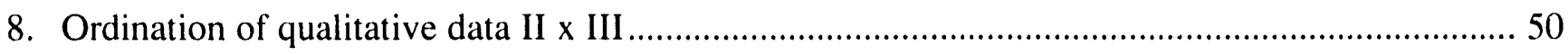

9. Minimum spanning tree for quantitative data by individual and location designation ................ 51

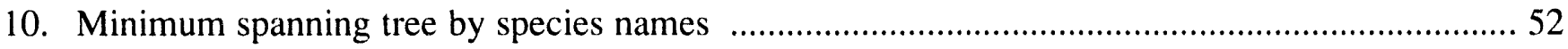

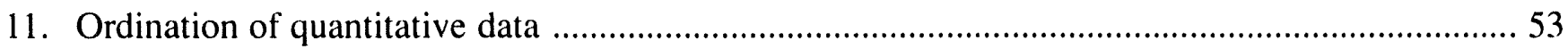

12. Ordination of quantitative data, remove MST ..................................................................... 54

13. Distribution of nominal species placed into the synonymy of E. complanata or E. icterina

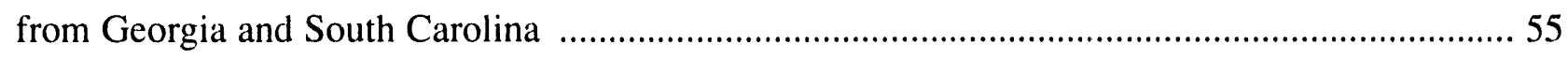

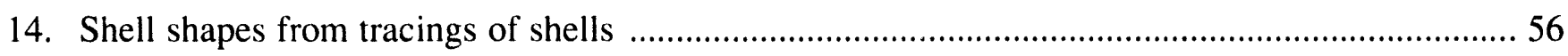

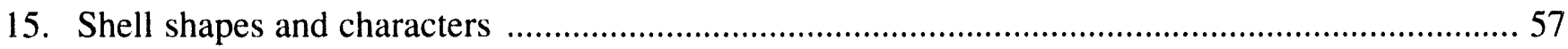

16. Dorsal and ventral margins as they depart from being parallel .......................................... 58 


\section{SUMMARY VIEWPOINT}

1. Elliptio hepatica from Mill Creek and Tinker Creek is both rare and endangered. It is a morphologically distinct species.

2. There is an Elliptio complanata complex in eastern North America. Nei's D is very low among clearly discrete species (morphologically and ecologically) (Davis et al., 1981). For example, $D=0.055 \pm$ $0.029(\mathrm{~N}=9)$ comparing four allopatric populations of $E$. complanata with E. waccamaw'ensis and E. cistelliformis from Lake Waccamaw, North Carolina. Nine allopatric populations of E. icterina from southwestern Florida had $D=0.097 \pm 0.05$ (range of $0.025-0.184$ ). It is clear that genetic distance by itself will not serve to distinguish species of the E. complanata complex. E. errans, E. icterina, E. lugubris, E. raveneli and E. complanata of this project belong to the $E$. complanata complex in the larger sense; E. icterina is removed from the complex when considering the species in this study.

3. E. icterina from the Savannah River differs from other taxa of the E. complanata complex by $\mathrm{D}=$ $0.113 \pm 0.032$.

4. Shell phenotypes and comparative anatomy seem to be better indicators of discrete species or discrete infraspecific taxa than are measures of genetic distance. We do not see evidence that these shell phenotypes are ecophenotyes. Therefore, it is clear that previous workers have lumped together discrete taxa under the names of E. icterina, E. lanceolata and E. complanata.

5. Comparison of allele frequencies at defined loci between congeneric sympatric species is most useful to disclose potentially distinct species. Such a comparison together with anatomical data confirm that Mill Creek Elliptio belong to two species: E. complanata and E. hepatica. E. hepatica is clearly distinct from E. icterina.

6. The following are hypotheses that require study:

(1) Sympatric Elliptio populations differing in size and shell phenotype reflect different cohorts where glochidia were shed from different fish populations (fish population A from the creek where the sympatric bivalves were collected; fish population B from another creek but invading the creek in question). As the glochidia-fish interaction is parasitic, the fish immune system may be selective on bivalve genes involving morphology and allozymes. As fish populations diverge geographically through time, so may the unionid genome.

(2) Sympatric Elliptio populations differing in size and phenotype reflect different cohorts of the same population. The different age classes may have different allele frequencies at certain loci due to the effect of fish on the glochidia where the fish for one cohort may be different than the fish hosting the other cohort (even to different fish species). 
(3) There may be considerable introgression of genes if (1) above occurs. The degree of introgression may considerably affect shell size and morphology.

(4) Shell phenotypes truly reflect discrete species existing in sympatry. The species complex has evolved and diverged too recently for allozymes to diverge very much. Given the recent divergence there is a certain amount of hybridization and introgression.

(5) Divergence is older in geologic time but stabilizing selection maintains low genetic divergence of structural genes of adult bivalves where the enzymes involved do the same job for adult clams of different species living much the same way. Greater genetic divergence is seen in the glochidial stage.

7. The Elliptio complex of the Savannah River Plant environments is diverse and complicated relative to assessing exact species status. This diversity is not simply sorted using allozymes and anatomy and requires future study using a tool such as MtDNA. The problem reflects a possibly important "natural experiment" in the pattern and process of speciation of an important macroinvertebrate faunal element in South Carolina and Georgia. Major components of this "natural experiment" sit on the Savannah River Site and in the Savannah River itself. These sites require protection as the distribution of several of the taxa involved is apparently limited.

8. Given these new findings, and our lack of knowledge, the following courses of action are advised in order of priority.

(1) Assemble a computerized database on the known occurrence of nominal species of Unionidae from the states of Georgia and South Carolina (nomens given to discrete shell phenotypes). Records are housed with voucher specimens in several major museums. Data gathered would include date of collection, exact locality, and river drainage system. Rationale: All that is known about the distribution of species in time and space must come from specimens in collections. Certain species have apparently not been recorded from these states in over 100 years. The database, once created, will permit precise assessment of the baseline distribution of species as collected, recorded, and vouchered by diverse researchers. The baseline is essential to indicate the extent to which the states must be surveyed to establish the current status of the bivalve fauna. How else can one answer the question: What is the distribution of living populations of Elliptio hepatica?

(2) Simultaneous with (1) above; do a careful unionid survey of the Savannah River from above the Savannah River Site to the point of salt water incursion (4\%). Rationale: Our sampling in the river for this study and subsequent routine station sampling by the staff of ANSP has indicated an alarming reduction in species collected and species abundance for what could be collected. It is alarming to find only one specimen each of Uniomerus obesus and Elliptio icterina (type locality); no specimens of $E$. folliculata (type locality). What is left in the river? What has caused this apparent massive decline? The river used to be species rich and with great specimen abundance. 
(3) Obtain sufficient E. hepatica, E. errans, E. lugubris, E. raveneli to do a definitive study of their comparative anatomy and gill-brooding morphology. Simultaneously obtain tissue to be deep frozen to facilitate MtDNA or DNA sequencing studies to provide a better genetic resolution than can be made using allozymes. Rationale: Too few specimens were available in this initial study to do a definitive anatomical study. The study was well under way before the full scope of species distinctions was made. It is necessary to study the brooding characteristics of these species.

(4) Work out the MtDNA - DNA techniques and begin applying them to species and subspecies discrimination of species of Elliptio. Rationale: Georgia and South Carolina are hotbeds of species evolution and diversity within the species-rich genus Elliptio. No scientific attention has been given to the problems of species diversity, distribution, and extinction within these contiguous states.

(5) Determine the fish hosts of these species. Rationale: The species of Elliptio can only reproduce in nature through larval parasitism on certain species of fish. The survival of the clams is dependent on the survival of these species of fish. See summary point 6 above. There may be considerable coevolution between fish and species of Elliptio. 


\title{
THE PROBLEM
}

Is there a population of Elliptio in Mill Creek that has previously been classified as E. icterina but which is in reality a distinct and different species of Elliptio? If so, is it rare or endangered?

\section{THE SPECIES PROBLEM}

Davis (1983, 1984) clearly demonstrated that authorities such as R. I. Johnson (i.e. in 1970) have lumped several species under a single name time and again. For example, Johnson (1970) followed by many others lumped all lanceolate Elliptio under E. lanceolata or E. shepardiana (Davis, 1984, using allozymes showed that at least five discrete lanceolate species belong to three different clades). Johnson (1970) and nearly all others have recognized only one species of Uniomerus (U. tetralasmus). Davis $(1983,1984)$ showed that there were at least three different species of Uniomerus with as much genetic distance among them as among all species of Elliptio thus far studied. Further, Uniomerus is genetically (allozymes) far removed from all species of Elliptio thus far studied.

Johnson, Fuller, Britton and many others would simply lump all the taxa studied here under four species of two genera (Table 1). They base their decisions only on conchology with the exception of Fuller who has used some anatomical and breeding condition characters. It was Fuller who stated that a Mill Creek population of Elliptio might not be E. icterina because of marsupium characters (Britton and Fuller, 1979, p. 10). Johnson's (1970) classification is shown in Table 2.

It is clear that the inability of those studying only shells to partition shell phenotypic variation into the relative contributions of genetics, ecology (ecophenotypes), and ontogeny has caused them to lump considerable variation under a single name. This has been a mistake. Generalities can be applied to species recognition when lessons are learned by coupling conchology, anatomy, molecular genetics, and ecology. In the case of Uniomerus, it is clear that shells with distinctive phenotypes have been shown, using molecular genetics, to be discrete species. Hence, as the Uniomerus of the Savannah River does not have the shell phenotype of $U$.tetralasmus, it is highly probable that it is not that species; hence, it should be called $U$. obesus (the shell corresponds to the type of $U$. obesus).

\section{METHODS}

\author{
Nomenclature and Disclaimer
}

\section{Localities}

Specimens were collected during mid-August 1989 from seven stations located on the Savannah River Site, Aiken and Barnwell Counties, South Carolina (Fig. 1). One station was in the Savannah River; four were from the Upper Three Runs Creek drainage, one each from the Pen Branch Creek and Lower Three Runs drainages. These three drainages flow to the Savannah River. 


\section{Nomenclature}

Species names were selected following comparisons of all specimens with extant types of nominal species of Elliptio and Uniomerus synonymized by Johnson under E. irterina, E. complanata, E. lanceolata and Uniomerus tetralasmus. The relevant types are housed in the Academy of Natural Sciences and the U.S. National Museum of Natural History. We selected the name based on the oldest nomen and type locality closest to the Savannah River Site and which involved specimens that most closely resembled the shells we collected. Further details are given in Appendix 1. The species we recognize are shown in Figs. 2 and 3 and are listed in Table 3. The control population was Elliptio complanata from Swartswood Lake, N.J. (See Davis et al. 1981).

As so many names have been given to every permutation and combination of phenotypes of Elliptio, there was no problem finding a name for the phenotypes of this study. The names thus given represent the best match for taxa named from the relevant geography. It is unlikely that differences among the phenotypes seen are due to ecological molding (ec'sphenotypes). When two clearly discernible phenotypes with different periostracal conditions cone from the same small stream where they live comingled, it is difficult to propose a scheme that wouid attribute differences seen to ecology.

\section{Electrophoresis}

Methods used are those well established (see Davis et al., 1981). Experimental conditions for running five systems not mentioned in Davis et al. (1981) are given below:

$\begin{array}{llll}\text { Enzyme } & \text { Buffer } & \text { Time (Hrs) } & \text { Current (MA) } \\ \text { NADD } & \text { TEB8 } & 3.5 & 35 \\ \text { CAT } & \text { TEB8 } & 3.5 & 35 \\ \text { ISDH } & \text { TM 7.4 } & 5.5 & 125 \mathrm{~V} \\ \text { EST } & \text { TC 8 } & 3.25 & 40 \\ \text { HBD } & \text { TEB 9/8 } & 2.0 & 35\end{array}$

\section{Anatomy}

Anatomical studies involved 48 individuals of 14 populations. Dissections were done using from one to 10 individuals depending on the specimens available. In the case of Elliptio icterina, no specimens from the Savannah River were available. Accordingly, anatomical data were derived from specimens identified as E. icterina from Magnolia Springs, Georgia. The anatomy of E. icterina presented here may not be the anatomy of genuine E. icterina (thus a disclaimer here).

Characters studied are listed in Tables 10 and 11; there were 11 qualitative and 26 quantitative characters, respectively. No clams studied were in a breeding condition so marsupial characters could not be scored. Matrices of OTUs X characters were subjected to multivariate analysis using NT-SYS (Rohlf et al., 1972)(Distance coefficients, Principal Component Analysis (PCA), Multidimensional Scaling (MDS) with subsequent ordination on various axes; Prime Network (= Minimum Spanning Tree; MST). 


\section{RESULTS}

\section{Electrophoresis}

We analyzed 16 populations (Table 4). Sample size (individuals used) per locus ranged from 1 to 26. Low sample sizes for 12 of the 16 populations precludes adequate analyses for fit to Hardy-Weinberg expectations. Data were derived from 20 loci including 69 alleles. Indexes of genetic variability are given in Table 5. Allele frequencies are given in Table 6.

Note: Elliptio complanata from Swartswood, New Jersey served as control and was used for all electrophoretic runs. Also, sympatric populations were run on the same gels with the control taxon. Finally, "N**" was used to indicate no enzyme activity at a locus.

In Tabie 7 are given sympatric species wliere there are apparently significant differences of allele frequencies at given loci. It is evident that the norninal taxa, as pre-sorted, are not panmictic.

Tables of Nei's (1972) genetic distance and Cavalli-Sforza and Edwards' (1967) Arc distance are given (Tables 8-9) with corresponding phenograms (Figs. 4, 5). A Wagner tree is given (Fig. 6).

\section{Anatomy: Qualitative Characters}

Factor loadings indicate that there are at least five PCs with significant information (Tables 12 and 13). These five PCs account for $98.8 \%$ of the variance. Character loading on each axis is given in Table 13. On the basis of 11 qualitative characters, it is possible to discern E. icterina, E. hepatica, E. folliculata, and New Jersey E. complanata from all others (Figs. 7, 8).

Axis I is an Elliptio icterina axis (35.4\% of variance).

$\begin{array}{cc}\text { Character } & \text { Factor Loading } \\ 4 & .854 \\ 5 & .854 \\ 6 & -.854 \\ 2 & -.798 \\ 9 & -.630\end{array}$

$\quad$ Nature of Character
complex water tubes
anal ligament fusing mantle edges
two pores in anal ligament
thick tissue layer in outer demibranch (shared with
E. complanata, NJ)
pigment type on strip bearing the papillae
(shared with some E. errans)

Axis II is an E. folliculata axis (29.75\% of variance).

$\begin{array}{cc}\text { Character } & \text { Factor Loading } \\ 7 & -.894 \\ 8 & -.894 \\ 10 & -.894\end{array}$

Nature of Character

suprabranchial strip of papillae with longer inner and shorter outer papillae anus and supra-anal shelf far dorsal to the branchial ligament base of major papillae wide, papillae have pyramidal shape 
Axis III is an E. hepatica [Mill Creek] (17.9\% of variance).

\begin{tabular}{ccl} 
Character & Factor Loading & \multicolumn{1}{c}{$\begin{array}{c}\text { Nature of Character } \\
1\end{array}$} \\
11 & -.932 & $\begin{array}{l}\text { the labial palps overlap the gills } \\
\text { a groove between mantle edge and flap of tissue supporting } \\
\text { suprabranchial papillae }\end{array}$
\end{tabular}

Axis IV is an E. complanata axis-New Jersey, UTR.1.
Character Factor Loading
Nature of Character
$3 \quad-.883$
cluster of small papillae at branchial ligament

Anatomy: Quantitative Characters

There were 12 PCs accounting for $91 \%$ of the variance (Table 14) of which the first eight axes $(80.15 \%$ of the variance) are the most informative. Character loadings on each PC are given in Table 15. An analysis of each of 8 axes is given in Table 16.

The most information is seen in the ordination diagrams with and without MST, and a linear presentation of the MST. The MST is drawn out in Fig. 9. Several points can be made: 1) DS.2.1(36) was widely separated from other DS.2 individuals. Re-examination of the shells revealed that this individual had the large shell of E. complanata, not of E. lugubris. Accordingly the individual in question was re-assigned to E. complanata. 2) E. cf icterina and E. folliculata are distinct, peripheral to $E$. complanata. 3) MC.2 (= E. hepatica) from Mill Creek is peripheral to MC.1 (= E. complanata $)$ solidly within the core mass of $E$. complanata.

Comparing Figs. 9 and 10, Elliptio hepatica and E. lugubris form a cluster to themselves far removed from E. icterinc and E. folliculata and Mill Creek E. complanata. Eliptio raveneli and E. errans are peripheral to E. lugubris and E. hepatica. E. complanata from New Jersey (EC.S) are peripheral to Savannah River Site E. complanata.

Considering ordination, the first axis was not informative as highest character loadings on the axis involved size-correlated structures. The $2 \times 3$ axes were much more informative (Figs. 11 and 12 ). The distribution of data on the 3rd axis separates New Jersey Elliptio complanata at the top with a mean of 20.5 minor papillae per unit measure versus E. complanata RB.1 and MC.1 from South Carolina with 13.0 per unit measure near the bottom. Mill Creek E. complanata and E. hepatica are not significantly different in this character. The number of filaments on the outer palp increases from top ( $\bar{x}$ of 15.5) to bottom ( $\overline{\mathrm{x}}$ of 22.8 for MC.1). Palp dimension " $C$ " decreases from top to bottom with a mean of $5.2 \mathrm{~mm}$ for $E$. complanata from New Jersey to $1.3 \mathrm{~mm}$ for $E$. folliculata. It is this and character 24 that place $E$. folliculata at the bottom of Figs. 11 and 12.

The number of radial bars per unit measure in the inner demibranch increases from 8.0 for New Jersey E. complanata at the top to 10 for E. folliculata at the bottom. Mill Creek E. complanata (MC.1) and E. hepatica (MC.2) are significantly different in this character. The distance between gills generally decreases from top to bottom as does the number of major papillae (but not perfectly).

Aside from these details, the anatomical data did not serve to clearly separate nominal species of the $E$. complanata complex into discrete regions of hyperspace. However, they were useful in showing that $E$. complanata from New Jersey is somewhat peripheral to the other populations. E. raveneli is scattered within the distribution of E. complanata. It is clear that Mill Creek populations are morphologically distinct, i.e. E. complanata and E. hepatica, respectively. 


\section{DISCUSSION: CONCHOLOGY AND ELECTROPHORESIS}

This study is clearly preliminary and explorative. Too few specimens were available for complete anatomical and electrophoretic analyses. Too few funds, time, and specimens were available to follow up with reanalyses of some populations by cross comparisons with others. However, the study does clearly indicate species-level complexity not properly understood before. It is clear that E. icterina from the Savannah River (compares well with the holotype from the Savannah River) is not what has been called E. icterina from Mill Creek and elsewhere in the creek systems of this study.

Simultaneous evaluation of the conchology, comparative anatomy and electrophoretic data are essential to sort out the species problem here. There are two major conclusions. 1) Uniomerus does diverge from Elliptio as expected on the results of Davis (1983) in spite of the fact that Uniomerus and Elliptio converage conchologically. 2) Topotypical E. icterina diverges considerably from taxa of the Elliptio complanata complex of that study.

The lanceolate populations of E. folliculata cluster together and differ from the species of the Elliptio complanata complex (E. complanata, E. errans, E. hepatica, E. lugubris, E. raveneli) by Nei's D of 0.103 . However, only Arc D serves to cluster these populations outside the $E$. complanata complex. Nominal taxa based on shell phenotypes that belong to the $E$. complanata species complex do not cluster together indicating the pervasiveness of the 69 alleles scored among the populations in question. That $E$. hepatica of Mill Creek is anatomically distinct as well as conchologically distinct from E. complanata of the same creek as well as from topotypical E. icterina (into which it had been placed in synonymy by Johnson (1970)) gives clear evidence that one cannot equate the genetic distance data with discrete species. Further evidence is given in Table 7 that shows two populations differing from sympatric populations of $E$. complanata by a Nei's D of 0.051 and 0.064 , respectively, yet the distribution of allele frequencies at 3 or 4 loci show that the populations are not panmictic.

Examining the shells and distribution of isozyme alleles of the species of the Elliptio complanata complex, as well as those of E. folliculata, one could make a case for hybridization and introgression. While the species discussed here appear to be valid, a hypothesis of divergence bridged at some point in the not too distant past by hybridization and introgression to various degrees seems to be warranted. To resolve this issue the tool of choice is probably MtDNA analysis.

The suites of anatomical characters used here for the first time are of considerable help in discriminating among species. The anatomical data are most useful when combined with genetic and conchological data. For example, anatomically Elliptio hepatica and E. lugubris fill the same region of hyperspace (Figs. 10, 12) and are far removed from E. icterina, E. folliculata and both Mill Creek sympatric (for E. hepatica) and New Jersey E. complanta. However, conchologically E. hepatica and E. lugubris are distinct. Anatomically E. errans appears to be peripheral to the E. hepatica - E. lugubris cluster, but more data are essential to make a definitive conclusion.

The two populations identified here as E. hepatica on the bases of conchology do have some discrete differences. Electrophoertically the Tinker Creek population has two alleles not shared with the Mill Creek population; the Mill Creek population has three such. They differ in two qualitative anatomical character states. The extent of the importance of these differences depends on a study involving more individuals from each population. Those populations are quite close to each other in the same drainage.

Britton and Fuller (1979, p. 10) emphasized the "peculiarities" of the Mill Creek Elliptio. Tne unique marsupium location was, in their minds, grounds for erecting a new genus. The unique taxon was in all other characters allied to E. icterina (their concept). Unfortunately, no voucher specimens for their paper were cataloged into the collections. No gravid females were seen in this study. What is clear is that 1) the 
Mill Creek Elliptio contains two discrete species: E. complanata and one with shells matching the holotype of E. hepatica. The anatomical, conchological, and allelic differences between the sympatric populations jointly confirm that there are two discrete species. Genetic data clearly indicate that Mill Creek E. hepatica is part of the Elliptio complanata species group; different generic placement is uncalled for.

As allozyme data do not serve to distinguish species-level taxa of the E. complanata species complex, and as there is considerable species-level complexity in the sites studied, it is highly recommended to initiate MtDNA studies as these techniques are sensitive at divergence levels not clearly distinguished using allozyme data. Further, anatomical studies are called for when 1) populations are gravid (AprilJuly), and 2) when more material can be obtained for some populations (e.g. E. icterina from the Savannah River, E. hepatica from Tinker Creek, and E. errans from Pen Branch).

\section{SUMMARY}

In conclusion, with Elliptio icterina from the Savannah River matching the shell of the holotype exactly, and being genetically and conchologically distinct from all the other taxa, it was clear that the traditional scheme of classification used for these stream Elliptio had to be modified. With two or three phenotypically separable groups (conchologically distinct) of taxa within a single site, all immediately sympatric, and with different allele frequencies at two or more loci, species names are justified until such time that MtDNA or other genomic studies indicate that the hypothesis of considerable historic hybridization and introgression is correct. A key to the species is provided in the Appendix. Elliptio lugubris and E. raveneli have strongly inflated shells that are also heavy shells per length. E. icterina has the distinctive regular convex edge. E. complanata has nearly parallel dorsal and ventral margins, is relatively compressed, reaches a large size, and has no defined posterior shelf. E. hepatica does not reach a large size, has a shell with a regularly rounded anterior end, and a dorsal margin rising at a wide angle; it has a wide posterior shelf. E. errans does not reach a large size, has a shell with a blunt, high flattened curve at the anterior end. The dorsal margin rises at a moderate angle; it has a wide posterior shelf.

It is emphasized that the names ultimately chosen were selected after exhaustive examination of extant types of species of Elliptio named from localities in both Georgia and South Carolina. 


\section{LITERATURE CITED}

Britton, J. C. and S. L. H. Fuller. 1979. The Freshwater Bivalve Mollusca of the Savannah River Plant, South Carolina. Savannah River Plant; SRO-NERP-3:pp. 1-37.

Cavalli-Sforza, L. L. and A. W. F. Edwards. 1967. Phylogenetic analysis: models and estimation procedures. Evolution 21:550-570.

Davis, G. M. 1983. Relative roles of molecular genetics, anatomy, morphometrics and ecology in assessing relationships among North American Unionidae. Systematics Association Special Volume No. 24: Protein Polymorphism: Adaptive and Taxonomic Significance. Oxford, G. S. and D. Rollinson, Eds. Academic Press, London, pp. 193-222.

Davis, G. M. 1984. Genetic relationships among some North American Unionidae: Sibling species, convergence, and cladistic relationships. Malacologia 25:629-648.

Davis, G. M., W. H. Heard, S. L. H. Fuller, and C. Hestermann. 1981. Molecular genetics and speciation in Elliptio and its relationship to other taxa of North American Unionidae. Biological Journal Linnean Soc. 15(2):131-150.

Johnson, R. I. 1970. The systematics and zoogeography of the Unionidae of the southern Atlantic Slope region. Bull. Mus. Comp. Zool. Harvard 140(6):263-249.

Nei, M. 1972. Genetic distance between populations. American Naturalist 106:283-292.

Nei, M. 1978. Estimation of average heterozygosity and genetic distance from a small number of individuals. Genetics 89:583-590.

Rohlf, E. J., J. Kisapaugh, and D. Kirk. 1972. NT-SYS: Numerical Taxonomy System of Multivariate Statistical Programs. Software, State University of New York, Stony Brook, NY.

Swofford, D. L. and R. B. Selander. 1981. BIOSYS-1 Users Manual. University of Illinois. Urbana, IL. 


\section{ACKNOWLEDGMENTS}

Support for this study was obtained from contract DE-AC09- 76SR00819 between the United States Department of Energy and the University of Georgia's Savannah River Ecology Laboratory. We thank Art Bogan and Michael C. Newman for assistance with field collections. Carol Hesterman performed the electrophoretic analysis. David Scott, Aline DeLaPerriere and Alexandra Webber provided the photographs and figures. The authors thank Miriam Culberson, Marianne Reneau, Patricia Davis, and Cheryl Badger for preparation of the manuscript. Finally, we thank Aline DeLaPerriere for the cover illustration and final preparation of the document. 
Table 1. Taxa reported by Britton and Fuller (1980) from the 7 sites.

Donora Station

E. icterina

E. complanata

U. tetralasmus

E. lanceolata

Mill Creek

E. icterina

E. complanata

E. lanceolata

Pen Branch
E. icterina
E. complanata
E. lanceolata

Reedy Branch
E. icterina
E. complanata
$U$. tetralasmus
E. lanceolata

Tinker Creek
E. icterina
E. complanata
$U$. tetralasmus
E. lanceolata

Upper Three Runs
E. icterina
E. complanata

Savannah River
E. congaraea
E. icterina
E. complanata
E. lanceolata
E. fraterna
U. tetralasmus 
Table 2. Synonymy according to Johnson (1970).

$\begin{array}{ll}\text { Elliptio } & \text { lanceolata } \\ & + \text { E. folliculata } \\ & \text { icterina } \\ & + \text { E. lugubris } \\ & + \text { E. raveneli } \\ & + \text { E. hepatica } \\ & \text { complanata } \\ & + \text { E. errans } \\ & \\ \text { Uniomerus tetralasmus } & + \text { U. obesus }\end{array}$


Table 3. Distribution of nominal species among the seven collection sites.

\section{Elliptio}

\section{Station}

1. E. complanata (Lightfoot) 1786

2. E. errans (Lea) 1834

3. E. folliculata (Lea) 1838

4. E. hepatica (Lea) 1859

5. E. icterina (Conrad) 1834

6. E. lugubris (Lea) 1834

7. E. raveneli (Conrad) 1834
Donora Station

Mill Creek

Reedy Branch

Tinker Creek

Upper Three Runs

Pen Branch

Donora Station

Reedy Branch

Mill Creek

Tinker Creek

Savannah River

Donora Station

Upper Three Runs

Pen Branch
Station Designation

DS.3

MC. 1

RB. 1

TC. 1

UTR.1

PB. 1

DS. 1

RB. 2

MC. 2

TC. 2

SR. 1

DS.2

UTR. 2

PB.2

\section{Uniomerus}


Table 4. Key to populations relative to the electrophoretic data.

\begin{tabular}{lll}
\hline $\begin{array}{l}\text { Species } \\
\text { Designation }\end{array}$ & Population name & Station \\
\hline E. complanata; EC & Mill Creek 1 & MC.1 \\
E. hepatica; EH & Mill Creek 2 & MC.2 \\
U. obesus; UO & Savannah River 2 & SR.2 \\
E. icterina; EI & Savannah River 1 & SR.1 \\
E. complanata; EC & Tinker Creek 1 & TC.1 \\
E. hepatica; EH & Tinker Creek 2 & TC.2 \\
E. folliculata; EF & Donora Station 1 & DS.1 \\
E. lugubris; EL & Donora Station 2 & DS.2 \\
E. complanaia; EC & Donora Station 3 & DS.3 \\
E. errans; EE & Pen Branch 1 & PB.1 \\
E. raveneli; ER & Pen Branch 2 & PB.2 \\
E. complanata; EC & Reedy Branch 1 & RB.1 \\
E. folliculata; EF & Reedy Branch 2 & RB.2 \\
E. complanata; EC & Upper Three Runs 1 & UTR.1 \\
E. lugubris; EL & Upper Three Runs 2 & UTR.2 \\
E. complanata; EC.S & Swartswood, NJ & EC.S \\
\hline
\end{tabular}


Table 5. Genetic variability at 20 loci in all populations (standard errors in parentheses). For definitions of (EC), etc. see Table 4.

\begin{tabular}{|c|c|c|c|c|c|c|}
\hline \multirow[b]{2}{*}{ Population } & \multirow[b]{2}{*}{$\begin{array}{l}\text { Mean sample } \\
\text { size per }\end{array}$} & \multirow[b]{2}{*}{$\begin{array}{l}\text { Mean no. } \\
\text { of alleles } \\
\text { per locus }\end{array}$} & \multirow[b]{2}{*}{$\begin{array}{l}\text { Percentage } \\
\text { of loci } \\
\text { polymorphic* }\end{array}$} & \multicolumn{2}{|c|}{ Mean heterozygosity } & \\
\hline & & & & $\begin{array}{l}\text { Direct- } \\
\text { count }\end{array}$ & $\begin{array}{l}\text { HdyWbg } \\
\text { expected** }\end{array}$ & \\
\hline \multirow{2}{*}{$\begin{array}{l}\text { 1. Mill Creek } 1 \\
\text { (EC) }\end{array}$} & 26.0 & 1.5 & 25.0 & .037 & .072 & \\
\hline & $(.0)$ & $(.2)$ & & $(.016)$ & $(.033)$ & \\
\hline \multirow{2}{*}{$\begin{array}{l}\text { 2. Mill Creek } 2 \\
(\mathrm{EH})\end{array}$} & 24.6 & 1.4 & 20.0 & .024 & .047 & \\
\hline & $(.2)$ & $(.2)$ & & $(.014)$ & $(.023)$ & \\
\hline \multirow{2}{*}{$\begin{array}{l}\text { 3. Savannah River } 2 \\
\text { (UO) }\end{array}$} & 1.0 & 1.1 & 15.0 & .150 & .150 & \\
\hline & $(.0)$ & $(.1)$ & & $(.082)$ & $(.082)$ & \\
\hline \multirow{2}{*}{$\begin{array}{l}\text { 4. Savannah River } 1 \\
\text { (EI) }\end{array}$} & 1.0 & 1.1 & 10.0 & .100 & .100 & \\
\hline & $(.0)$ & $(.1)$ & & (.069) & $(.069)$ & \\
\hline \multirow{2}{*}{$\begin{array}{l}\text { 5. Tinker Creek } 1 \\
\text { (EC) }\end{array}$} & 10.0 & 1.5 & 25.0 & .060 & .106 & \\
\hline & $(.0)$ & $(.3)$ & & $(.028)$ & $(.051)$ & \\
\hline \multirow{2}{*}{$\begin{array}{l}\text { 6. Tinker Creek } 2 \\
(\mathrm{EH})\end{array}$} & 10.0 & 1.3 & 20.0 & .040 & .060 & \\
\hline & $(.0)$ & $(.1)$ & & $(.020)$ & $(.029)$ & $\cdot$ \\
\hline \multirow{2}{*}{$\begin{array}{l}\text { 7. Donora Station } 1 \\
\text { (EF) }\end{array}$} & 6.0 & 1.2 & 20.0 & .042 & .070 & \\
\hline & $(.0)$ & $(.1)$ & & $(.027)$ & $(.035)$ & \\
\hline \multirow{2}{*}{$\begin{array}{l}\text { 8. Donora Station } 2 \\
\text { (EL) }\end{array}$} & 10.0 & 1.6 & 40.0 & .115 & .134 & \\
\hline & $(.0)$ & $(.3)$ & & $(.044)$ & $(.050)$ & \\
\hline \multirow{2}{*}{$\begin{array}{l}\text { 9. Donora Station } 3 \\
\text { (EC) }\end{array}$} & 9.6 & 1.5 & 30.0 & .120 & .122 & \\
\hline & $(.4)$ & $(.3)$ & & $(.058)$ & $(.054)$ & \\
\hline \multirow{2}{*}{$\begin{array}{l}\text { 10. Pen Branch } 1 \\
\text { (EE) }\end{array}$} & 4.9 & 1.4 & 25.0 & .100 & .124 & \\
\hline & $(.0)$ & $(.2)$ & & $(.057)$ & $(.054)$ & \\
\hline \multirow{2}{*}{$\begin{array}{l}\text { 11. Pen Branch } 2 \\
\text { (ER) }\end{array}$} & 15.0 & 1.8 & 40.0 & .110 & .131 & \\
\hline & $(.0)$ & $(.3)$ & & $(.042)$ & $(.045)$ & \\
\hline \multirow{2}{*}{$\begin{array}{l}\text { 12. Reedy Branch } 1 \\
\text { (EC) }\end{array}$} & 20.0 & 1.6 & 35.0 & .120 & .106 & \\
\hline & $(.0)$ & $(.2)$ & & $(.046)$ & $(.038)$ & \\
\hline \multirow{2}{*}{$\begin{array}{l}\text { 13. Reedy Branch } 2 \\
\text { (EF) }\end{array}$} & 1.0 & 1.1 & 15.0 & .150 & .150 & \\
\hline & $(.0)$ & $(.1)$ & & $(.082)$ & $(.082$ & \\
\hline \multicolumn{2}{|c|}{ 14. Upper Three Runs 110.0} & 1.4 & 30.0 & .115 & .113 & \\
\hline \multicolumn{2}{|c|}{$\begin{array}{ll}\text { (EC) } & (.0)\end{array}$} & $(.2)$ & & $(.052)$ & $(.045)$ & \\
\hline \multicolumn{2}{|c|}{ 15. Upper Three Runs 210.0} & 1.6 & 30.0 & .100 & .110 & \\
\hline$(\mathrm{EL})$ & $(.0)$ & $(.2)$ & & $(.052)$ & $(.041)$ & \\
\hline \multirow{2}{*}{$\begin{array}{l}\text { 16. Swartswood } \\
\text { (EC.S) }\end{array}$} & 22.0 & 1.7 & 30.0 & .082 & .123 & \\
\hline & $(.0)$ & (.3) & & $(.032)$ & $(.048)$ & \\
\hline
\end{tabular}

* A locus is considered polymorphic if more than one allele was detected.

** Unbiased estimate (see Nei, 1978). 
Table 6. Allele frequencies in populations 1 thru 16. EC, etc. defined in 'Table 4.

\begin{tabular}{cccccccccccccccccc}
\hline 110 \\
\hline & EC & EH & UO & EI & EC & EH & EF & EL & EC & EE & ER & EC & EF & EC & EL & EC.S \\
& MC.1 & MC.2 & SR.2 & SR.1 & TC.1 & TC.2 & DS.1 & DS.2 & DS.3 & PB.1 & PB.2 & RB.1 & RB.2 UTR.1 UTR.2 NJ \\
Locus & 1 & 2 & 3 & 4 & 5 & 6 & 7 & 8 & 9 & 10 & 11 & 12 & 13 & 14 & 15 & 16 \\
\hline
\end{tabular}

\section{GPI}

$\begin{array}{lllllllllllllllll}\text { (N) } & 26 & 25 & 1 & 1 & 10 & 10 & 6 & 10 & 20 & 5 & 15 & 20 & 1 & 10 & 10 & 22 \\ \mathrm{~A} & .83 & .90 & & 1.00 & .95 & 1.00 & .83 & .95 & .75 & 1.00 & 1.00 & .80 & 1.00 & .95 & .80 & .84 \\ \mathrm{~B} & .08 & .02 & & & .05 & & & & .25 & & & .08 & & .05 & .05 & .11 \\ \mathrm{C} & .06 & .08 & & & & & & .05 & & & & .13 & & & & .02 \\ \mathrm{D} & .02 & & & & & & & & & & & & & & & \\ \mathrm{E} & .02 & & & & & & .17 & & & & & & & & & .03 \\ \mathrm{~F} & & & .50 & & & & & & & & & & & & & \\ \mathrm{G} & & & .50 & & & & & & & & & & & & & \\ \mathrm{H} & & & & & & & & & & & & & & & & \\ \mathrm{H} & & & & & & & & & & & & & & & & \end{array}$

\section{PGM1}

$\begin{array}{lllllllllllllllll}\text { (N) } & 26 & 23 & 1 & 1 & 10 & 10 & 6 & 10 & 10 & 5 & 15 & 20 & 1 & 10 & 10 & 22\end{array}$

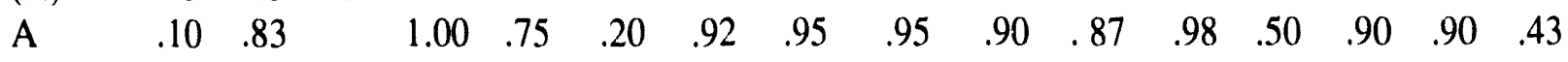

$\begin{array}{lllllllll}\text { B } & .90 & .17 & .98 & .05 & .10 & .07 & .50 & .52\end{array}$

$\begin{array}{lll}\mathrm{C} & 1.00 \quad .05\end{array}$

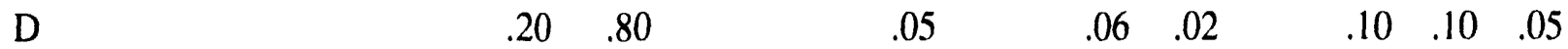

\section{PGM2}

$\begin{array}{lllllllllllllllll}\text { (N) } & 26 & 25 & 1 & 1 & 10 & 10 & 6 & 10 & 10 & 5 & 15 & 20 & 1 & 10 & 10 & 22 \\ \mathrm{~A} & .96 & 1.0 & & .50 & .50 & .75 & .75 & .90 & .95 & .40 & .70 & .83 & & .75 & .65 & .75 \\ \mathrm{~B} & .04 & & & .50 & .10 & & .25 & .10 & & .30 & 04 & .02 & .50 & .25 & .05 & .07 \\ \mathrm{C} & & & & & .20 & & & & .05 & & & .13 & .50 & & & \\ \mathrm{D} & & & 1.00 & & .10 & .25 & & & & & .13 & & & & .20 & .18 \\ \mathrm{E} & & & & & .10 & & & & & .30 & .13 & .02 & & & .10 & \end{array}$


Table 6.(continued)

\begin{tabular}{ccccccccccccccccc}
\hline 1110 \\
& EC & EH & UO & EI & EC & EH & EF & EL & EC & EE & ER & EC & EF & EC & EL & EC.S \\
& MC.1 & MC.2 & SR.2 & SR.1 & TC.1 & TC.2 & DS.1 & DS.2 & DS.3 & PB.1 & PB.2 & RB.1 & RB.2 UTR.1 UTR.2 NJ \\
Locus & 1 & 2 & 3 & 4 & 5 & 6 & 7 & 8 & 9 & 10 & 11 & 12 & 13 & 14 & 15 & 16 \\
\hline
\end{tabular}

\section{LAP}

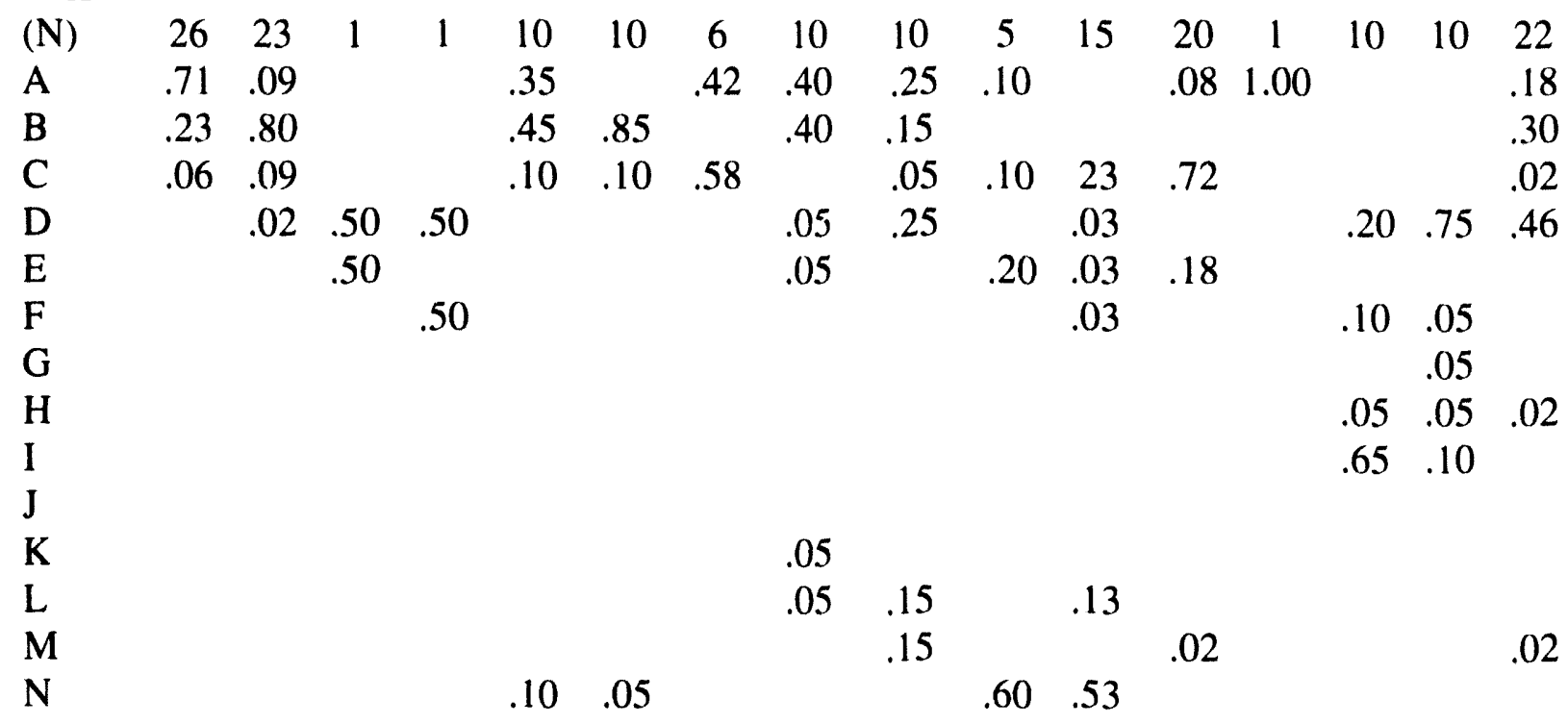

\section{MDH1}

$\begin{array}{lllllllllllllllll}\text { (N) } & 26 & 25 & 1 & 1 & 10 & 10 & 6 & 10 & 10 & 5 & 15 & 20 & 1 & 10 & 10 & 22\end{array}$

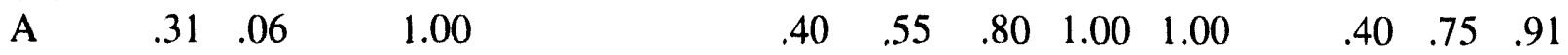

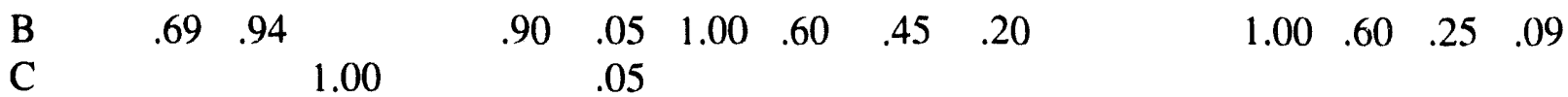

$\mathrm{D}$

$\mathrm{E}$ $.10 \quad .90$

ME

$\begin{array}{lllllllllllllllll}\text { (N) } & 26 & 25 & 1 & 1 & 10 & 10 & 6 & 10 & 10 & 4 & 15 & 20 & 1 & 10 & 10 & 22\end{array}$

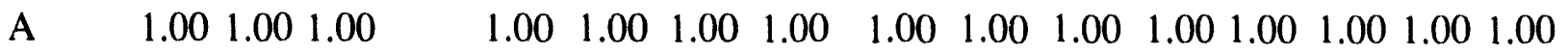
B $\quad 1.00$

\section{SOD1}

$\begin{array}{lllllllllllllllll}\text { (N) } & 26 & 25 & 1 & 1 & 10 & 10 & 6 & 10 & 10 & 5 & 15 & 20 & 1 & 10 & 10 & 22\end{array}$ $\begin{array}{lllllllllllllllll}\text { A } & 1.00 & 1.00 & 1.00 & 1.00 & 1.00 & 1.00 & 1.00 & 1.00 & 1.00 & 1.00 & 1.00 & 1.00 & 1.00 & 1.00 & 1.00 & 1.00\end{array}$

\section{SOD2}

$\begin{array}{lllllllllllllllll}\text { (N) } & 26 & 25 & 1 & 1 & 10 & 10 & 6 & 10 & 10 & 5 & 15 & 20 & 1 & 10 & 10 & 22\end{array}$

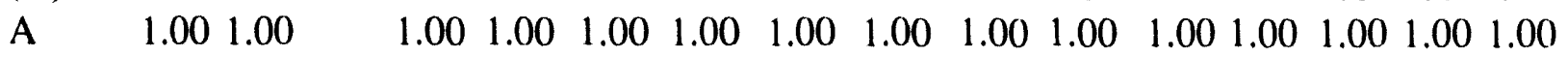
B $\quad 1.0^{\prime}$ 
Table 6.(continued)

\section{Population}

$\begin{array}{llllllllllllllll}\text { EC } & \text { EH } & \text { UO } & \text { EI } & \text { EC } & \text { EH } & \text { EF } & \text { EL } & \text { EC } & \text { EE } & \text { ER } & \text { EC } & \text { EF } & \text { EC } & \text { EL } & \text { EC.S }\end{array}$

MC.1 MC.2 SR.2 SR.1 TC.1 TC.2 DS.1 DS.2 DS.3 PB.1 PB.2 RB.1 RB.2 UTR.1 UTR.2 NJ

$\begin{array}{lllllllllllllllll}\text { Locus } & 1 & 2 & 3 & 4 & 5 & 6 & 7 & 8 & 9 & 10 & 11 & 12 & 13 & 14 & 15 & 16\end{array}$

\section{EST1}

$\begin{array}{lllllllllllllllll}(\mathrm{N}) & 26 & 25 & 1 & 1 & 10 & 10 & 6 & 10 & 10 & 5 & 15 & 20 & 1 & 10 & 10 & 22\end{array}$

$\begin{array}{llllllllllllllll}\text { A } & 1.00 & 1.00 & 1.00 & 1.00 & 1.00 & 1.00 & 1.00 & & 1.00 & 1.00 & 1.00 & 1.00 & 1.00 & 1.00 & 1.00\end{array}$

B $\quad 1.00$

$\mathrm{N}^{* *} \quad 1.00$

EST2

$\begin{array}{lllllllllllllllll}(\mathrm{N}) & 26 & 25 & 1 & 1 & 10 & 10 & 6 & 10 & 10 & 5 & 15 & 20 & 1 & 10 & 10 & 22\end{array}$

$\begin{array}{lllllllllllllllll}\mathrm{A} & 1.00 & 1.00 & 1.00 & 1.00 & 1.00 & 1.00 & 1.00 & 1.00 & 1.00 & 1.00 & 1.00 & .88 & 1.00 & 1.00 & 1.00 & 1.00\end{array}$

B .13

\section{EST3}

$\begin{array}{lllllllllllllllll}\text { (N) } & 26 & 25 & 1 & 1 & 10 & 10 & 6 & 10 & 10 & 5 & 15 & 20 & 1 & 10 & 10 & 22\end{array}$

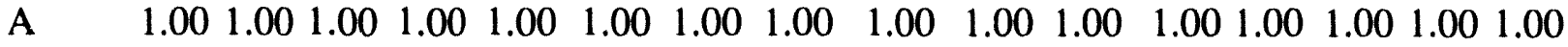

\section{MDH2}

$\begin{array}{lllllllllllllllll}\text { (N) } & 26 & 25 & 1 & 1 & 10 & 10 & 6 & 10 & 10 & 5 & 15 & 20 & 1 & 10 & 10 & 22\end{array}$

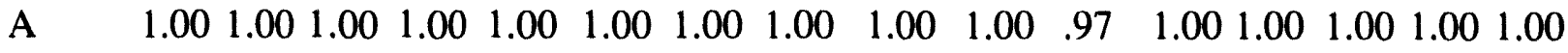

C

.03

OCT

$\begin{array}{lllllllllllllllll}\text { (N) } & 26 & 25 & 1 & 1 & 10 & 10 & 6 & 10 & 10 & 5 & 15 & 20 & 1 & 10 & 10 & 22\end{array}$

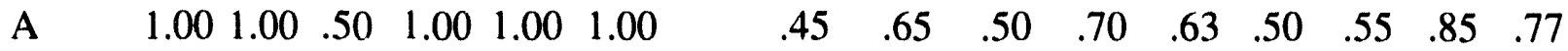

$\begin{array}{llllllllllll}\mathrm{B} & .50 & 1.00 & .45 & .35 & .50 & .30 & .38 & .50 & .45 & .15 & .23\end{array}$

C

.10

\section{ISDH1}

$\begin{array}{lllllllllllllllll}\text { (N) } & 26 & 25 & 1 & 1 & 10 & 10 & 6 & 10 & 10 & 5 & 15 & 20 & 1 & 10 & 10 & 22\end{array}$ $\begin{array}{llllllllllllllll}\text { A } & 1.00 & 1.00 & 1.00 & 1.00 & 1.00 & 1.00 & 1.00 & 1.00 & 1.00 & .90 & 1.00 & 1.00 & 1.00 & 1.00 & 1.00\end{array}$ B $\quad 1.00 \quad .10$

\section{HBDH}

$\begin{array}{lllllllllllllllll}\text { (N) } & 26 & 25 & 1 & 1 & 10 & 10 & 6 & 10 & 10 & 5 & 15 & 20 & 1 & 10 & 10 & 22\end{array}$

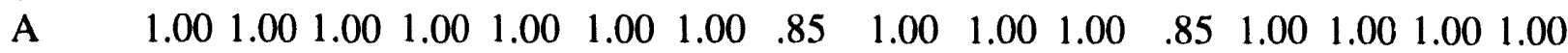

B 
Table 6.(continued)

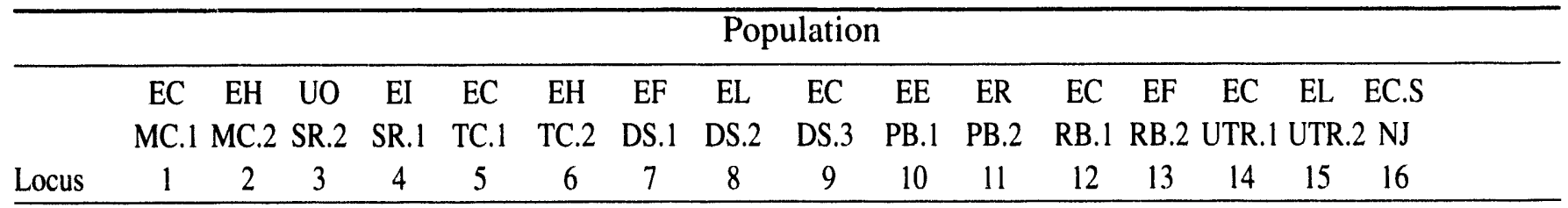

\section{CAT1}

$\begin{array}{lllllllllllllllll}\text { (N) } & 26 & 25 & 1 & 1 & 10 & 10 & 6 & 10 & 10 & 5 & 15 & 20 & 1 & 10 & 10 & 22\end{array}$

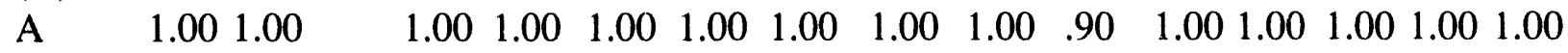
B $\quad 1.00$

C .10

\section{CAT2}

$\begin{array}{lllllllllllllllll}\text { (N) } & 26 & 24 & 1 & 1 & 10 & 10 & 6 & 10 & 10 & 5 & 15 & 20 & 1 & 10 & 10 & 22\end{array}$

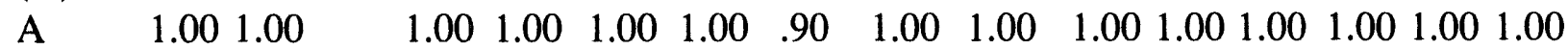

B $\quad 1.00$

$\mathrm{C} \quad .10$

\section{NADD1}

$\begin{array}{lllllllllllllllll}\text { (N) } & 26 & 24 & 1 & 1 & 10 & 10 & 6 & 10 & 10 & 5 & 15 & 20 & 1 & 10 & 10 & 22\end{array}$

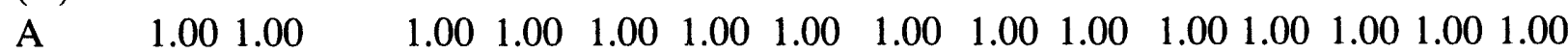

B $\quad 1.00$

\section{NADD2}

$\begin{array}{lllllllllllllllll}\mathrm{N}) & 26 & 24 & 1 & 1 & 10 & 10 & 6 & 10 & 10 & 5 & 15 & 20 & 1 & 10 & 10 & 22\end{array}$

$\begin{array}{llllllllllllllll}\mathrm{A} & 1.00 & 1.00 & 1.00 & 1.00 & 1.00 & 1.00 & 1.00 & 1.00 & 1.00 & .80 & 1.00 & 1.00 & 1.00 & 1.00 & 1.00\end{array}$

$\begin{array}{llllll}\mathrm{B} & 1 & 1.00 & .03\end{array}$

$\begin{array}{ll}\mathrm{C} & .17\end{array}$

\section{ISDH2}

$\begin{array}{lllllllllllllllll}\text { (N) } & 26 & 24 & 1 & 1 & 10 & 10 & 6 & 10 & 10 & 5 & 15 & 20 & 1 & 10 & 10 & 22\end{array}$ A $\quad \begin{array}{llllllllllllllll}1.00 & 1.00 & 1.00 & 1.00 & 1.00 & 1.00 & 1.00 & 1.00 & 1.00 & 1.00 & 1.00 & 1.00 & 1.00 & 1.00 & 1.00 & 1.00\end{array}$ 
Table 7. The case for sympatric species based on allele frequencies.

Case I. Mill Creek

$$
\begin{aligned}
& \text { (MC.1) } \\
& N=26
\end{aligned}
$$

E. complanata

PGM.1

A

B

LAP

MDH. 1

A

B

C

D

A $\quad .31$

B

Unique alleles

Case II. Tinker Creek

.10

.90

.71

.23

.06

()

.31

69

3

TC.1
$\mathbf{N}=\mathbf{1 0}$

E. complanata

PGM.I

A

C

D

PGM.2

A

B

C

D

E

LAP

MDH.1
A
B
C
$\mathrm{N}$

.75

.05

.20

.50

.10

.2()

.10

.10

TC.2

$\mathbf{N}=10$

E. hepatica

.20)

.80

.75

()

()

.25

()
0

.83

.17

09

(09)

.02

.06

94

()
Nei's $(1978) D=.051$

$\operatorname{Arc}=.170$
Nei's (1978) $D=.064$

Arc $=.224$ 
Case III. Donora Station

GPI $\quad$ A

PGM. 2

$\begin{array}{ll}\mathrm{A} & .75 \\ \mathrm{~B} & .25 \\ \mathrm{C} & 0\end{array}$

EST.1

$\begin{array}{ll}\mathrm{A} & 1.00\end{array}$

$\mathrm{N}$

OCT

$\mathrm{HBDH}$

LAP

MDH.1

A $\quad .83$

B

C

E
DS.1

$N=6$

\section{E. folliculata}

$$
0
$$

0

.17
DS.2

$\mathrm{N}=10$

E. lugubris

.95

0

.05

0

.90

.10

0

1.00

0

.45

.45

.10

.85

.15

.40

.40

0

.05

.05

.05

.05

0

.40

.60

PB.2

$\mathrm{N}=15$

E. raveneli

E. errans

PGM.2

MDH.1

$\begin{array}{cc}\mathrm{A} & 0 \\ \mathrm{~B} & 1.00\end{array}$

PB.1

$\mathrm{N}=5$

.40

.30

0

.30

.80

.20
.70

.04

.13

.13

1.00

$\begin{array}{ccc}\mathrm{E} & .30 & .13 \\ \mathrm{~A} & .80 & 1.00\end{array}$

$$
\begin{array}{cr}
\text { DS.3 } & 1 \times 2 \\
N=10 & \text { Nei's }(1978) D=.035 \\
\text { Arc }=247
\end{array}
$$

\section{E. complanata}

.75

.25

0

0
$2 \times 3$
Nei's (1978) $D=.065$ Arc $=.283$

.95

0

.05

0

1.00

.65

.35

0

1.00

0

.25

.15

.05

.25

0

0

.15

.15

.55

.45 


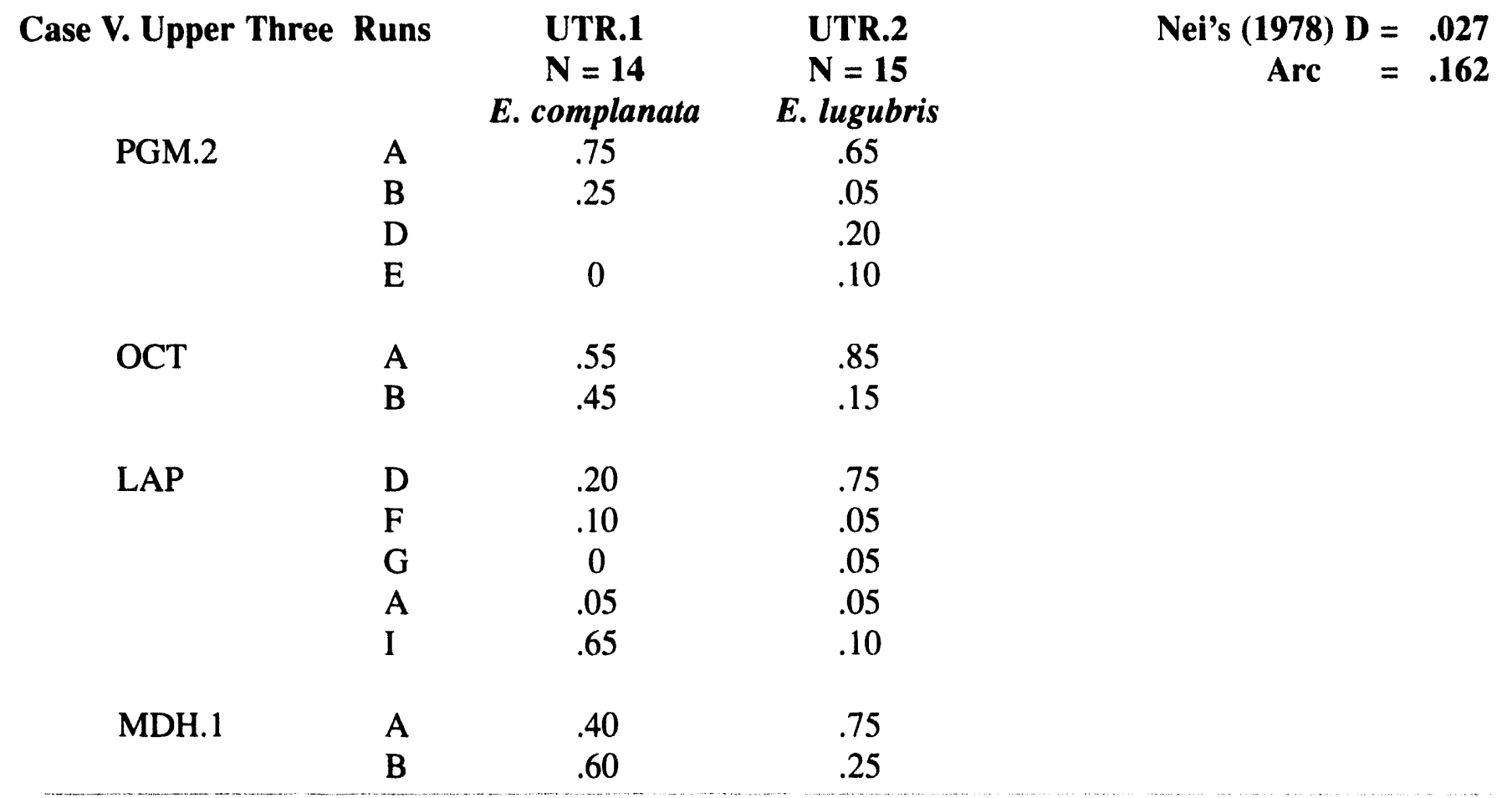


Table 8. Matrix of Nei's (1972) genetic distance.

\begin{tabular}{|c|c|c|c|c|c|c|c|c|c|c|c|c|c|c|c|c|}
\hline Population & $\begin{array}{c}\text { EC } \\
1\end{array}$ & $\begin{array}{c}\mathrm{EH} \\
2\end{array}$ & $\begin{array}{c}\text { UO } \\
3\end{array}$ & $\begin{array}{c}\text { EI } \\
4\end{array}$ & $\begin{array}{c}\mathrm{EC} \\
5\end{array}$ & $\begin{array}{c}\mathrm{EH} \\
6\end{array}$ & $\begin{array}{c}\text { EF } \\
7\end{array}$ & $\begin{array}{c}\text { EL } \\
8\end{array}$ & $\begin{array}{c}\mathrm{EC} \\
9\end{array}$ & $\begin{array}{c}\mathrm{EE} \\
10\end{array}$ & $\begin{array}{c}\text { ER } \\
11\end{array}$ & $\begin{array}{c}\mathrm{EC} \\
12\end{array}$ & $\begin{array}{c}\text { EF } \\
13\end{array}$ & $\begin{array}{r}\text { EC } \\
14\end{array}$ & $\begin{array}{l}\text { EL } \\
15\end{array}$ & $\begin{array}{c}\text { EC.S } \\
16\end{array}$ \\
\hline 1. Mill Creek 1 & -- & & & & & & & & & & & & & & & \\
\hline 2. Mill Creek 2 & .052 & --- & & & & & & & & & & & & & & \\
\hline 3. Savannah River 2 & .905 & .917 & -- & & & & & & & & & & & & & \\
\hline 4. Savannah River 1 & .178 & .156 & 1.022 & $-\cdots$ & & & & & & & & & & & & \\
\hline 5. Tinker Creek 1 & .054 & .017 & .869 & .145 & --- & & & & & & & & & & & \\
\hline 6. Tinker Creek 2 & .108 & .077 & .873 & .195 & .069 & --- & & & & & & & & & & \\
\hline 7. Donora Station 1 & .116 & .088 & .908 & .212 & .077 & .180 & -- & & & & & & & & & \\
\hline 8. Donora Station 2 & .063 & .031 & .894 & .128 & .034 & .102 & .042 & --. & & & & & & & & \\
\hline 9. Donora Station 3 & .125 & .097 & .864 & .168 & .099 & .164 & .119 & .073 & --- & & & & & & & \\
\hline 10. Pen Branch 1 & .105 & .091 & .869 & .104 & .070 & .132 & .079 & .042 & .099 & --- & & & & & & \\
\hline 11. Pen Branch 2 & .104 & .091 & .839 & .097 & .082 & .120 & .112 & .052 & .097 & .016 & $\cdots$ & & & & & \\
\hline 12. Reedy Branch 1 & .112 & .094 & .913 & .109 & .092 & .136 & .090 & .050 & .094 & .039 & .026 & --- & & & & \\
\hline 13. Reedy Branch 2 & .072 & .104 & .903 & .207 & .058 & .177 & .068 & .073 & .157 & .097 & .145 & .141 & $-\cdots$ & & & \\
\hline 14. Upper Three Runs 1 & .087 & .054 & .872 & .113 & .048 & .115 & .055 & .027 & .083 & .042 & .052 & .057 & .089 & $\cdots$ & & \\
\hline 15. Upper Three Runs 2 & .092 & .069 & .813 & .079 & .061 & .110 & .110 & .046 & .081 & .044 & .036 & .045 & .127 & .034 & $\cdots$ & \\
\hline 16. Swartswood & .047 & .067 & .825 & .097 & .070 & .093 & .118 & .045 & .090 & .047 & .036 & .046 & .112 & .053 & .024 & -- \\
\hline
\end{tabular}


Table 9. Matrix of Cavalli-Sforza \& Edwards (1967) arc distance.

\begin{tabular}{lcccccccccccccccc}
\hline & EC & EH & UO & EI & EC & EH & EF & EL & EC & EE & ER & EC & EF & EC & EL & EC.S \\
Population & 1 & 2 & 3 & 4 & 5 & 6 & 7 & 8 & 9 & 10 & 11 & 12 & 13 & 14 & 15 & 16 \\
\hline
\end{tabular}

1. Mill Creek 1

2. Mill Creek 2

$170 \quad-.-$

3. Savannah River 2

4. Savannah River 1

$\begin{array}{rrr}.783 & .779 \quad-\cdots\end{array}$

5. Tinker Creek 1

$\begin{array}{rrrr}.403 & .384 & .797 & --\end{array}$

6. Tinker Creek 2

$\begin{array}{llllll}244 & .179 & .762 & .410 & \cdots\end{array}$

7. Donora Station 1

$\begin{array}{lllll}.334 & .274 & .756 & .438 & .224\end{array}$

8. Donora Station 2

$\begin{array}{lllllll}.307 & .299 & .783 & .455 & .300 & .403 & --\end{array}$

9. Donora Station

$\begin{array}{lllllll}.225 & .189 & .766 & .364 & .240 & .333 & .247\end{array}$

10. Pen Branch 1

$\begin{array}{llllllllll}.333 & .302 & .762 & .411 & .321 & .391 & .350 & .283 & \ldots\end{array}$

11. Pen Branch 2

$\begin{array}{llllllllll}.285 & .291 & .763 & .355 & .276 & .369 & .271 & .233 & .337 & \ldots\end{array}$

12. Reedy Branch 1

$\begin{array}{llllllllll}.330 & .319 & .732 & .340 & .321 & .342 & .347 & .387 & .340 & .177\end{array}$

13. Reedy Branch 2

$\begin{array}{lllllllllll}.310 & .299 & .767 & .360 & .317 & .361 & .309 & .266 & .316 & .220 & .225\end{array}$

$\begin{array}{lllllllllllll}.275 & .318 & .775 & .444 & .266 & .425 & .257 & .277 & .382 & .298 & .399 & .370\end{array}$

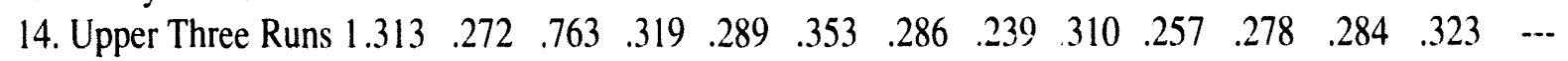

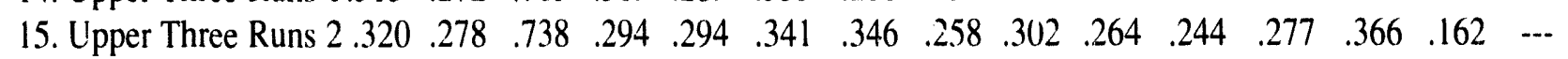

16. Swartswood

$\begin{array}{llllll}.196 & .218 & .742 & .327 & .275 & .314\end{array}$

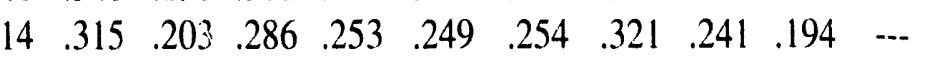


Table 10. Data matrix A; Qualitative characters (11) scored for 14 OTUs

\section{OTUs}

\section{Character}

EC EH EC.S EF EL EC EI EC EC EL EE ER EC EH

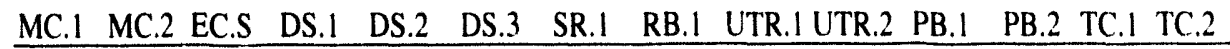

1. Labial palps overlap the gill

$\begin{array}{llllllllllllll}0 & 1 & 0 & 0 & 0 & 0 & 0 & 0 & 0 & 0 & 0 & 0 & 0 & 0\end{array}$

2. Tissue padding the outer demibranch especially thick, complex

3. Cluster of small papillae at $\quad \begin{array}{lllllllllllllll}0 & 0 & 1 & 0 & 0 & 0 & 0 & 0 & 1 & 0 & 0 & 0 & 0 & 0\end{array}$ the branchial ligament

4. Outer demibranch water tubes $\quad \begin{array}{lllllllllllllll}0 & 0 & 0 & 0 & 0 & 0 & 1 & 0 & 0 & 0 & 0 & 0 & 0 & 0\end{array}$ structure simple (0), complex (1)

5. The anal ligament lower, and between mantle edges

6. Two pores in anal ligament

7. Superbranchial strip of papillae has longer inner and shorter outer papillae

8. Anus and supra-anal shelf fa dorsal to branchial ligament

9. Strip bearing papillae:
A) black pigmented (0);
B) fingers of pigment between papillae only (1);
C) no pigment (2);
D) brown pigment (3)

10. Base of larger papillae wide giving papilla a pyramidal shape

11. Considerable groove between

$\begin{array}{llllllllllllll}0 & 0 & 0 & 0 & 0 & 0 & 1 & 0 & 0 & 0 & 0 & 0 & 0 & 0 \\ 0 & 0 & 0 & 1 & 0 & 0 & 0 & 0 & 0 & 0 & 0 & 0 & 0 & 0\end{array}$
edge and flap of tissue supporting the suprabranchial papillae 
Table 11. Characters measured or counted for 48 individuals of 14 populations.

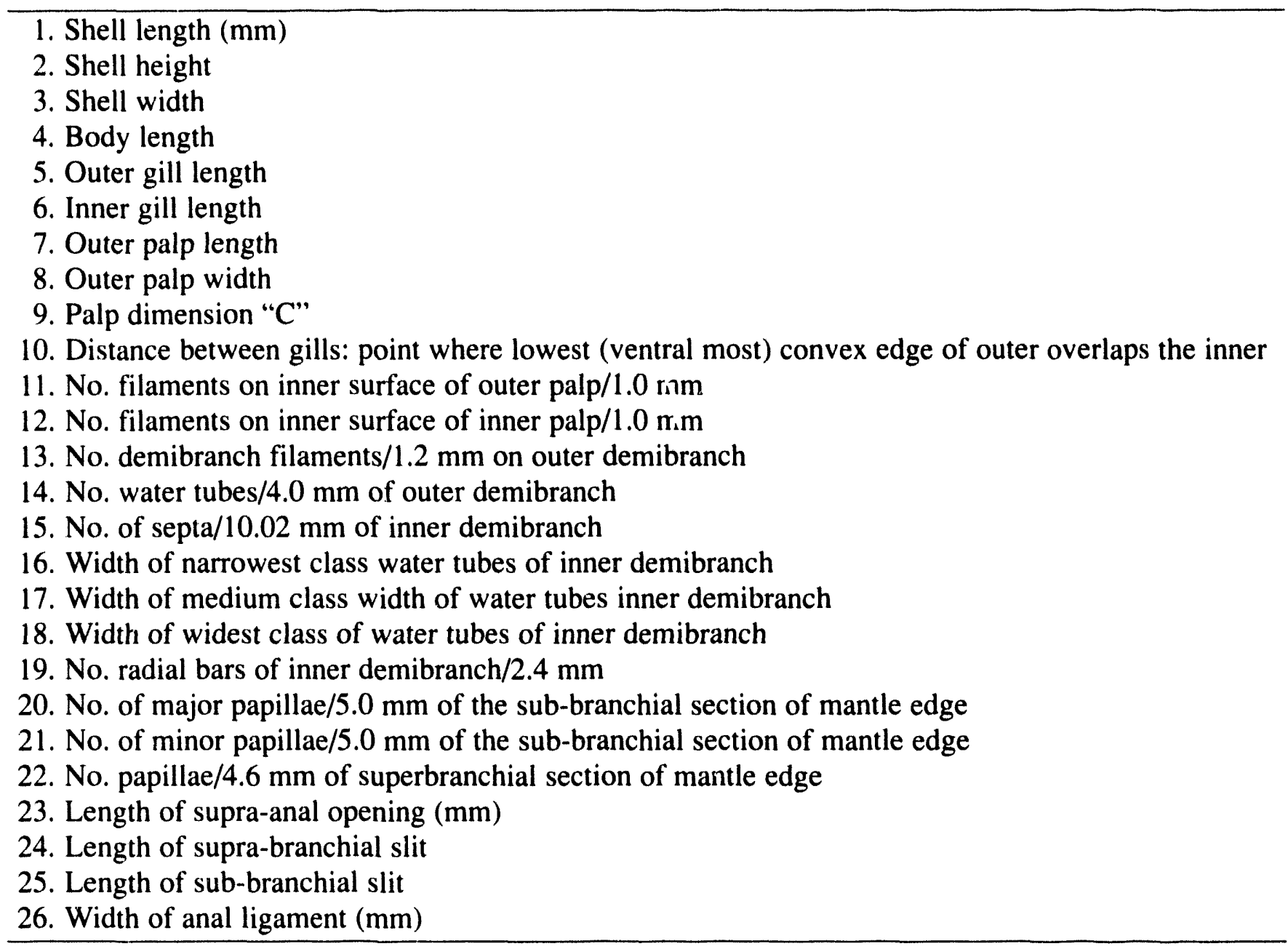


Table 12. Qualitative anatomical characters: Loadings on the five principle components beyond which eigen values drop to 0.523 . The first five PCs account for 98.8 percent of the variation.

\begin{tabular}{cccc}
\hline Principal Component & Eigen value & Percent & Cumulative \\
\hline 1 & 3.8953 & 35.41 & 35.41 \\
2 & 3.2726 & 29.75 & 65.16 \\
3 & 1.9733 & 17.94 & 83.10 \\
4 & 1.1990 & 10.90 & 94.00 \\
5 & 0.5233 & 4.76 & 98.76 \\
\hline
\end{tabular}


Table 13. Qualitative anatomical characters: Character loadings for the first five PCs. *, character 9 significant in this PC.

\begin{tabular}{cccccc}
\hline Characters & $\mathbf{1}$ & $\mathbf{2}$ & $\mathbf{P C s}$ & $\mathbf{3}$ & $\mathbf{5}$ \\
\hline 1 & 0.2747 & 0.1138 & 0.9323 & -0.2043 & 0.0267 \\
2 & -0.7980 & -0.2803 & -0.0084 & -0.4424 & 0.0140 \\
3 & 0.0646 & -0.0293 & -0.2597 & -0.8833 & 0.2517 \\
4 & 0.8540 & -0.4878 & -0.0892 & 0.0398 & 0.1377 \\
5 & 0.8540 & -0.4878 & -0.0892 & 0.0398 & 0.1377 \\
6 & -0.8540 & 0.4878 & 0.0892 & -0.0398 & -0.1377 \\
7 & -0.4161 & -0.8938 & 0.1448 & 0.0487 & -0.0207 \\
8 & -0.4161 & -0.8938 & 0.1448 & 0.0487 & -0.0207 \\
9 & -0.6295 & 0.2388 & 0.1372 & 0.3573 & $0.6326^{*}$ \\
10 & -0.4161 & -0.8938 & 0.1448 & 0.0487 & -0.0207 \\
11 & 0.2747 & 0.1138 & 0.9323 & -0.2043 & 0.0267 \\
\hline
\end{tabular}


Table 14. Loadings on the first $12 \mathrm{PCs}$ accounting for $91 \%$ of the variance involving quantitative characters; 26 PCs account for $100 \%$.

\begin{tabular}{cccc}
\hline Principal Component & Eigen value & Percent & Cumulative \\
\hline 1 & 8.0218 & 30.85 & 30.85 \\
2 & 3.2610 & 12.85 & 43.40 \\
3 & 2.9842 & 11.48 & 54.87 \\
4 & 1.8091 & 6.96 & 61.83 \\
5 & 1.3756 & 5.29 & 67.12 \\
6 & 1.2989 & 5.00 & 72.12 \\
7 & 1.0988 & 4.23 & 76.34 \\
8 & .9907 & 3.81 & 80.15 \\
9 & 0.8283 & 3.19 & 83.34 \\
10 & 0.6975 & 2.68 & 86.02 \\
11 & 0.6445 & 2.48 & 88.50 \\
12 & 0.5759 & 2.21 & 90.72 \\
\hline
\end{tabular}


Table 15. Character loading for the first five PCs involving quantitative anatomical data.

\begin{tabular}{|c|c|c|c|c|c|}
\hline \multicolumn{6}{|c|}{ PCs } \\
\hline Characters & 1 & 2 & 3 & 4 & 5 \\
\hline 1 & 0.9739 & 0.0062 & -0.0344 & 0.0823 & -0.0846 \\
\hline 2 & 0.9441 & 0.0507 & -0.0899 & -0.0964 & -0.0727 \\
\hline 3 & 0.8800 & 0.1889 & -0.0587 & -0.0696 & -0.0729 \\
\hline 4 & 0.9720 & -0.0439 & -0.0780 & 0.1063 & 0.0077 \\
\hline 5 & 0.9293 & 0.0927 & 0.0200 & 0.0610 & -0.1268 \\
\hline 6 & 0.9446 & 0.0193 & -0.0418 & 0.0790 & -0.0551 \\
\hline 7 & 0.8007 & 0.0205 & 0.3908 & 0.0790 & -0.0871 \\
\hline 8 & 0.3862 & -0.2476 & 0.2587 & -0.5870 & 0.1398 \\
\hline 9 & 0.2398 & -0.1066 & 0.5854 & -0.6220 & 0.0968 \\
\hline 10 & 0.01672 & -0.0565 & 0.4587 & -0.0129 & -0.0813 \\
\hline 11 & 0.0291 & -0.1990 & -0.6204 & -0.1872 & -0.3290 \\
\hline 12 & 0.2403 & -0.3167 & -0.4440 & -0.3201 & -0.3753 \\
\hline 13 & 0.1908 & 0.0444 & -0.3635 & -0.2043 & 0.6804 \\
\hline 14 & -0.0951 & 0.0329 & -0.0050 & 0.6544 & 0.0455 \\
\hline 15 & 0.0953 & 0.6360 & 0.2716 & -0.0969 & -0.2559 \\
\hline 16 & -0.0459 & -0.8150 & -0.0196 & 0.0783 & 0.0775 \\
\hline 17 & 0.0457 & -0.9135 & 0.0980 & 0.0179 & -0.0523 \\
\hline 18 & 0.0742 & -0.7991 & 0.1296 & 0.0397 & -0.2323 \\
\hline 19 & -0.1227 & 0.0925 & -0.5100 & -0.3440 & -0.0987 \\
\hline 20 & -0.3201 & 0.2049 & 0.4175 & 0.1180 & -0.5659 \\
\hline 21 & 0.2137 & -0.0331 & 0.6463 & 0.0988 & 0.1095 \\
\hline 22 & -0.3020 & -0.1972 & 0.2443 & 0.1216 & 0.3100 \\
\hline 23 & 0.6419 & -0.2231 & 0.1711 & 0.3854 & 0.0305 \\
\hline 24 & 0.5794 & -0.2692 & -0.4858 & 0.1104 & 0.0273 \\
\hline 25 & 0.8135 & -0.0378 & -0.2324 & 0.1785 & 0.0294 \\
\hline 26 & 0.2105 & 0.4866 & -0.2796 & -0.0260 & 0.1127 \\
\hline
\end{tabular}


Table 16. Characterization of 8 PCA axes; quantitative anatomical character loadings are given. Refer to Tables $11,14,15$.

Axis 1 . Size axis-all correlates of lengths $(=30.85 \%$ of variance).

Character Factor Loading

$\begin{array}{lll}1 & .974 & \text { shell length } \\ 2 & .944 & \text { shell height } \\ 3 & .880 & \text { shell width } \\ 4 & .972 & \text { body length } \\ 5 & .929 & \text { outer gill length } \\ 6 & .945 & \text { inner gill length } \\ 7 & .801 & \text { outer palp length } \\ 23 & .642 & \text { length of supra-branchial opening } \\ 24 & .813 & \text { length of sub-branchial opening }\end{array}$

Axis 2. Water tube diameter and width of anal ligament (= $12.5 \%$ of variance).

$\begin{array}{cll}\text { Character } & \text { Factor Loading } & \\ 17 & -.914 & \text { inner demibranch; intermediate width of water tube } \\ 16 & .815 & \text { inner demibranch; smallest width of water tube } \\ 18 & .799 & \text { inner demibranch; greatest width of water tube } \\ 15 & .636 & \text { inner demibranch; number of septa/10.02 mm } \\ 26 & .487 & \text { width of anal ligament }\end{array}$

Axis 3. Numbers: minor papillae; filaments on outer palp; radial bars on inner demibranch; no. of major papillae. Dimensions: "C" of palp; length of supra-branchial slit; distance between gills (= $11.48 \%$ of variance).

$\begin{array}{ccl}\text { Character } & \text { Factor Loading } & \\ 21 & .646 & \text { no. minor papillae } \\ 11 & -.621 & \text { no. filaments on outer palp } \\ 9 & .585 & \text { palp dimension "C" } \\ 19 & -.510 & \text { no. radial bars-inner demibranch } \\ 24 & -.486 & \text { length of supra-branchial slit } \\ 10 & .459 & \text { distance between gills } \\ 20 & .417 & \text { no. major papillae }\end{array}$

Axis 4. No. water tubes-outer demibranch; palp dimension " $\mathrm{C}$ "; palp width (=7\% of variance; accumulation $\mathbf{= 6 1 . 8 \%}$ ).

Character

14

9

8
Factor Loading

$-.587$ no. water tubes

palp dimension " $\mathrm{C}$ "

palp width 
Table 16. (continued)

Axis 5. No. demibranch filaments; no. major papillae $(=5.3 \%$ of variance $)$.

Character

13

20
Factor Loading

.680

$-.566$ no. demibranch filaments

no. major papillae

Axis 6. No. papillae; width of anal ligament (= $5 \%$ of variance).

Character

$$
22
$$$$
26
$$

Factor Loading

$$
.512
$$

no. papillae

width of anal ligament

Axis 7. Distance between gills $(=4.2 \%$ of variance).

Character Factor

10
Loading

$-.586$

distance between gills

Axis 8. Distance between gills; no. radial bars.

Character

10

\section{Factor Loading}


Appendix I. Selection of species names and descriptions.

In this study we found individuals from a single locality that could be readily sorted to as many as three different phenotypes. As shell phenotypes and periostracal characters were different, it was clear that different species were involved, not ecophenotypes. As our specimens of Elliptio from the Savannah River had a shell that matched the type specimen of E. icterina, and the specimen differed from the other populations genetically, and had a shell phenotype different from phenotypes seen in the creek populations, none of the creek populations could be considered to be E. icterina.

One of us (Davis) examined the numerous type specimens named by Conrad and especially Lea from Georgia and South Carolina, some 58 in all, to attempt to find the earliest possible name for a shell phenotype that matched shell phenotypes of our study, and that of the type locality as close as possible to the Savannah River Site. All of the relevant types are housed at either the Academy of Natural Sciences of Philadelphia or at the U.S. National Museum of Natural History, Washington, D.C.

As shown in Fig. 13, the distribution of nominal species placed into the synonymy of E. complanata or E. icterina is far from a random distribution throughout these states. No species were named from the eastern part of South Carolina, i.e. east of the Black River. There were 58 relevant synonyms, 32 under E. complanata and 26 under E. icterina. Of these, $43(74 \%)$ came from Georgia and $15(26 \%)$ from South Carolina. There were two nomen-rich counties: Muscogee County, Georgia at the mid-western edge of Georgia with 12 nominal species, and Abbeville County on the Savannah River, South Carolina with 7 nominal species (combined $=33 \%$ of nominal species). Burke County on the Savannah River, Georgia was another nomen-rich node with 8 nominal species (Buckhead Creek was obviously a favorite collecting place). Six nominal taxa come from the Flint River drainage, Georgia from Decatur County on the Florida border upstream including Dougherty Co., Lee County, Dooley and Macon Counties.

As we had populations that were attributable to Elliptio icterina (type locality, Savannah River, South Carolina, opposite Augusta, Georgia; close to where we collected it) and E. complanata, we needed names for four additional phenotypes in the E. complanata species group. The best fits available were:

1. Unio raveneli Conrad (May) 1834. Wateree Canal in the vicinity of the Santee Canal, South Carolina. The Santee Canal connects Lake Moultrie to the Cooper River in Berkeley County northeast of Moncks Corner close to where routes 52 and $17 \mathrm{~A}$ intersect.

Synonym: $U$. confertus Lea (August or September 1834. Santee Canal (type lost; topotype available). Precisely the same phenotype as $U$.raveneli.

2. U. lugubris Lea 1834. Hopton, near Darien, McIntosh Co., Georgia, Altamaha River drainage near the ocean.

Synonym: $U$. geddingsianus Lea 1840 from the Congaree River, South Carolina.

U. toumeyi Lea 1852 from Abbeville Co., Savannah River drainage, South Carolina.

3. U. hepaticus Lea 1859. Salkehatchie River, South Carolina. The county was not given. This river has its headwaters in Barnwell Co., close to the Savannah River Site.

4. U. errans Lea 1856. Near Macon, Bibb Co., Georgia. Bibb Co. is mid-state and the drainage is to the Ocmulgee River that flows to the Altamaha River. 
The lanceolate Elliptio is E. folliculata (Lea) 1838: type locality; Savannah River, Georgia. The phenotype is quite distinct compared with that of E. lanceolata (Lea) 1826 from the Tar River, North Carolina. 


\section{Appendix II. Species Descriptions}

A key is presented to permit identification of the Elliptio covered in this study. The key is accompanied by illustrations of characters and character-states (Figs. 14-16).

1a. Shell lanceolate $(\mathrm{H} / \mathrm{L}=0.38 \pm 0.03)$ E. folliculata

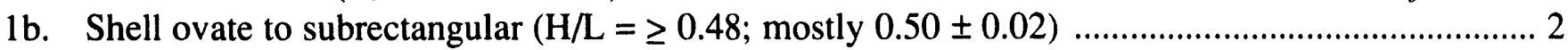

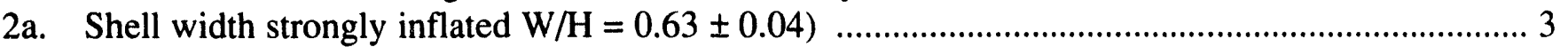

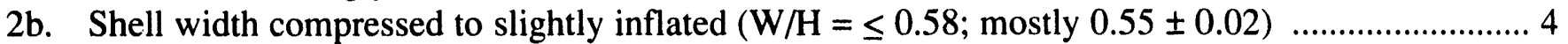

3a. Anterior end regularly rounded (Rr, Fig. 15. B), dorsal margin arcuate (Apdm, Fig 15. E), ridges vague on some shells (Dmr, Fig. 15. D) E. lugubris

3b. Anterior end blunt, flattened curve (Br, Fig. 15. D), posterior dorsal margin angular (Ang, Fig. 15. D), no ridges evident E. raveneli

4a. Anterior end regularly rounded 5

4b. Anterior end blunt, high flattened curve (Br, Fig. 15. D) 6

5a. Shell subelliptical (Fig. 15. A), ventral edge convex (Cm, Fig. 15. A), major ridge single or doubled (Bmr, Fig. 15. A), strong and angular; secondary or minor ridge present (Mr, Fig. 15. A) leaving a narrow shelf (Ns, Fig. 15. A). Posterior end pointed (Ppe, Fig. 15. A) to very short posterior truncation (Pts, Fig. 15. C). E. icterina

5b. Shell irregularly elliptical being expanded posteriorly; dorsal margin rising at a wide angle (Asa, Fig. 15. E); slight major ridge, no minor ridge; very wide shelf (Ws, Fig. 15. B; E), posterior end with moderately high truncation (Ptm, Fig. 15. B). E. hepatica

6a. Dorsal and ventral margins parallel or nearly so in most individuals (Fig. 15. B); no defined shelf, posterior dorsal margin with angulation (Ang, Fig. 15. D); posterior truncation long (Ptl, Fig. 15. D). No defined shelf, ventral margin may have a depression (Vmd, Fig. 15. D). .... E. complanata

6b. Shell trapezoidal (Fig. 14. A) with dorsal margin rising at a moderate angle; posterior dorsal margin arcuate; posterior truncation of moderate length; with wide shelf. Ventral margin without a depression.

E. errans 
Figure 1. Collection locations and major drainages of the Savannah River Site.

TC - Tinker Creek at SRS Road 2.1 and SRS Road 8.1.

UTR - Upper Three Runs at the Aquatic Ecology Laboratory upstream of SRS Road C.

SR - Savannah River upstream of the confluence with Upper Three Runs.

RB - Reedy Branch at SRS Road 2.1.

MC - Mill Creek at SRS Road E.2.

PB - Pen Branch at the SRS Road B bridge.

DS - Lower Three Runs downstream of the railroad trestle at Donora Station. 


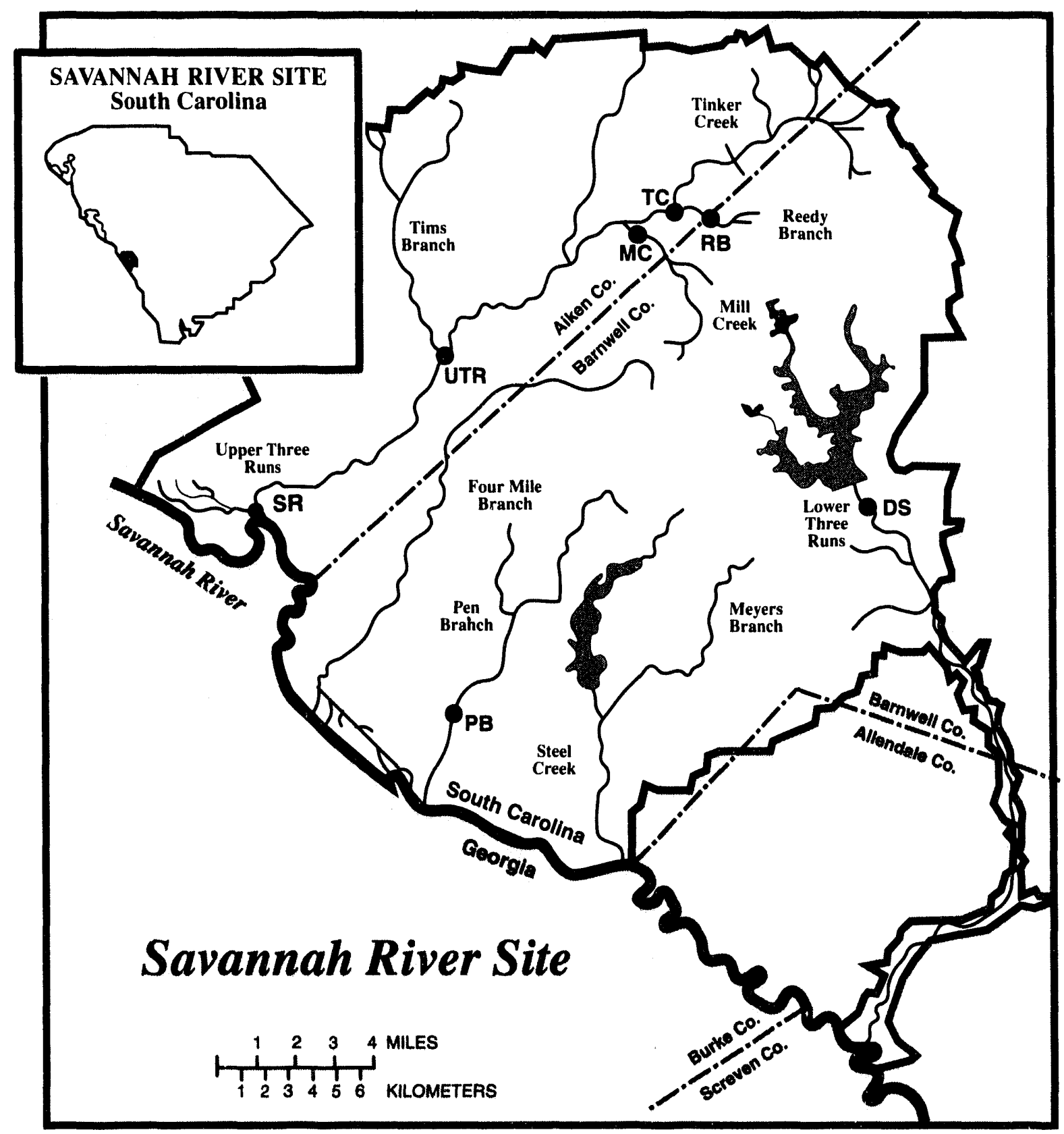




\section{Figure 2}

Figure 1. Elliptio folliculata. Collected from the Donora Station location on Lower Three Runs. ANSP 376054 . Shell length is $81.76 \mathrm{~mm}$, height is $29.37 \mathrm{~mm}$.

Figure 2. Elliptio icterina. Collected from Beaver Creek, North Carolina. ANSP 127076.

Figure 3. Elliptio icterina. Collected from Savannah River. ANSP 376053.

Figure 4. Elliptio lugubris. Collected from the Donora Station location on Lower Three Runs. ANSP 376957.

Figure 5. Elliptio lugubris. Collected from the Donora Station location on Lower Three Runs. ANSP 376956.

Figure 6. Elliptio errans. Collected from Pen Branch. ANSP 376034.

Figure 7. Elliptio errans. Collected from Pen Branch. ANSP 376035.

Figure 8. Elliptio hepatica. Collected from Mill Creek. ANSP 376050.

Figure 9. Elliptio complanata. Juvenile collected from Mill Creek. ANSP 376051.

Figure 10. Elliptio hepatica. Collected from Mill Creek. ANSP 376051. 


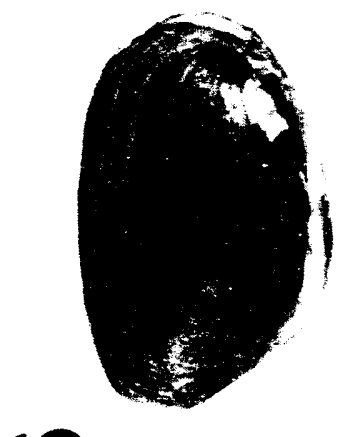

0

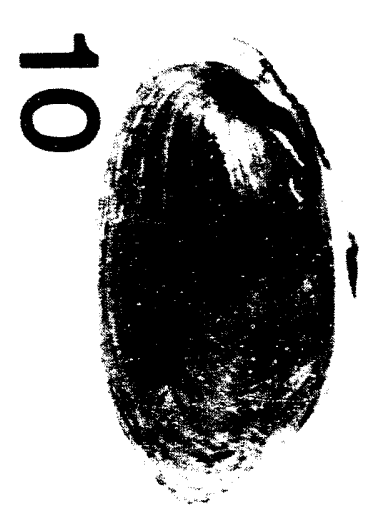

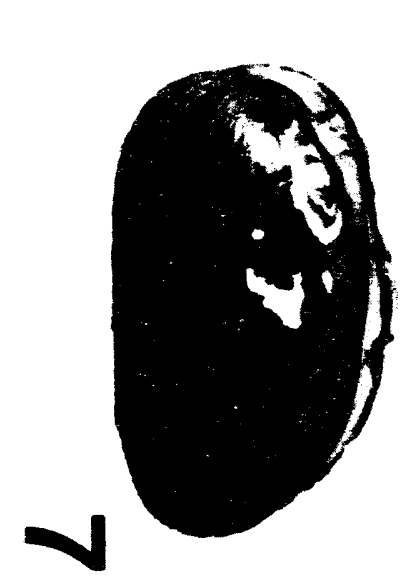
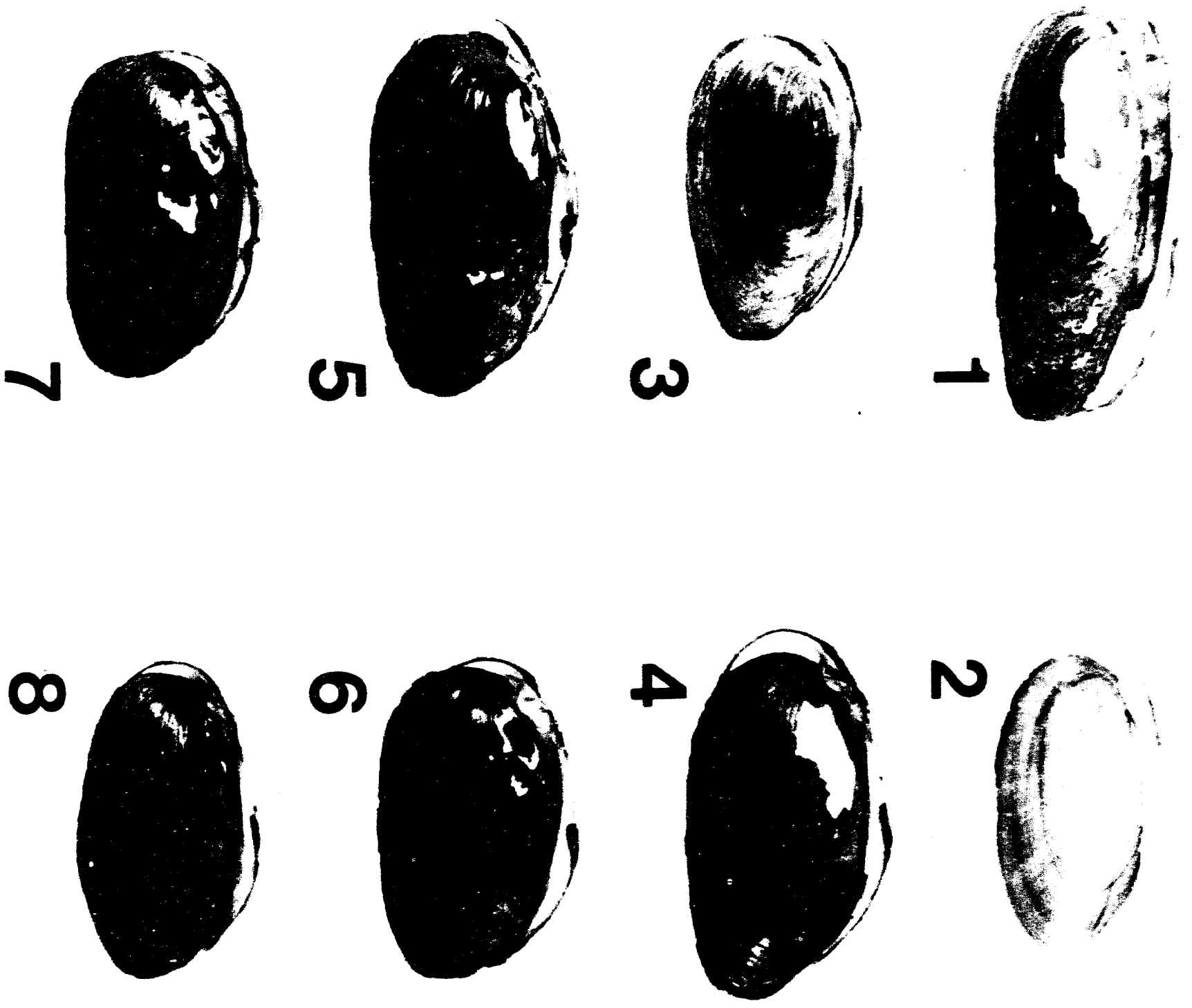


\section{Figure 3.}

Figure 1. Elliptio lugubris. Collected from the Donora Station location on Lower Three Runs. AN S P 376057. Shell length is $61.85 \mathrm{~mm}$, height is $29.83 \mathrm{~mm}$.

Figure 2. Elliptio folliculata. Collected from Reedy Branch. ANSP 376060.

Figure 3. Elliptio lugubris. Collected from the Donora Station location on Lower Three Runs. ANSP 376057.

Figure 4. Elliptio hepatica. Collected from Mill Creek. ANSP 376050.

Figure 5. Elliptio raveneli. Collected from Pen Branch. ANSP 376037.

Figure 6. Elliptio raveneli. Collected from Pen Branch. ANSP 376036.

Figure 7. Elliptio complanata. Collected from Mill Creek. ANSP 376048.

Figure 8. Elliptio complanata. Collected from the Donora Station location on Lower Three Runs. ANSP 376059.

Figure 9. Elliptio complanata. Collected from the Donora Station location on Lower Three Runs. ANSP 376059.

Figure 10. Elliptio complanata. Collected from the Donora Station location on Lower Three Runs. ANSP 376059. 


$$
\begin{aligned}
& 00000 \\
& 00000
\end{aligned}
$$




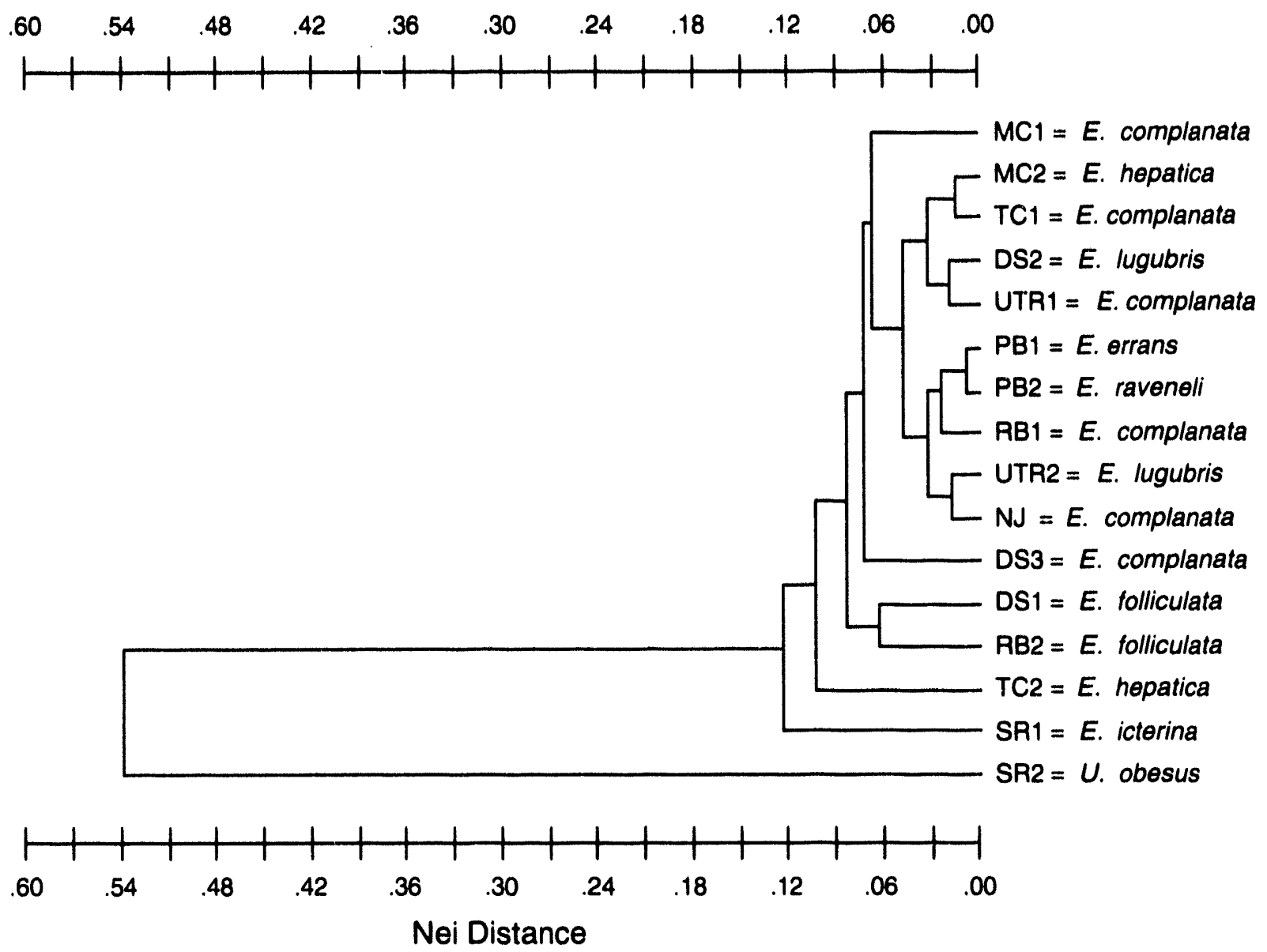

Figure 4. Phenogram of electrophoretic data using Nei genetic distance and UPGMA. 

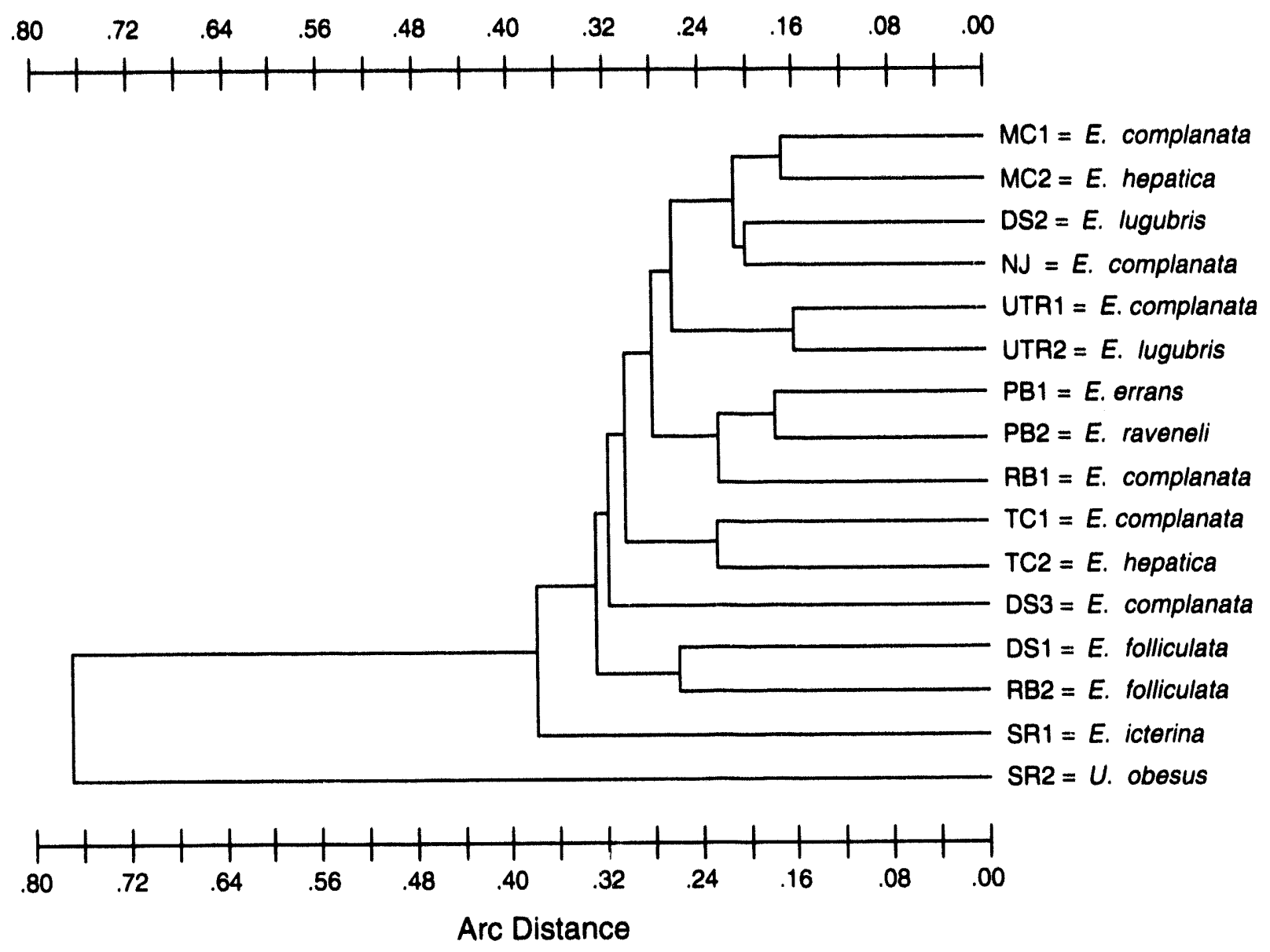

Figure 5. Phenogram of electrophoretic data using Cavalli-Sforza arc distance and UPGMA. 
Wagner tree produced by rooting at midpoint of longest point

Total length of tree $=2.627$

$\begin{array}{lllllllllll}.00 & .05 & .10 & .15 & .20 & .25 & .30 & .35 & .40 & .45 & .50\end{array}$

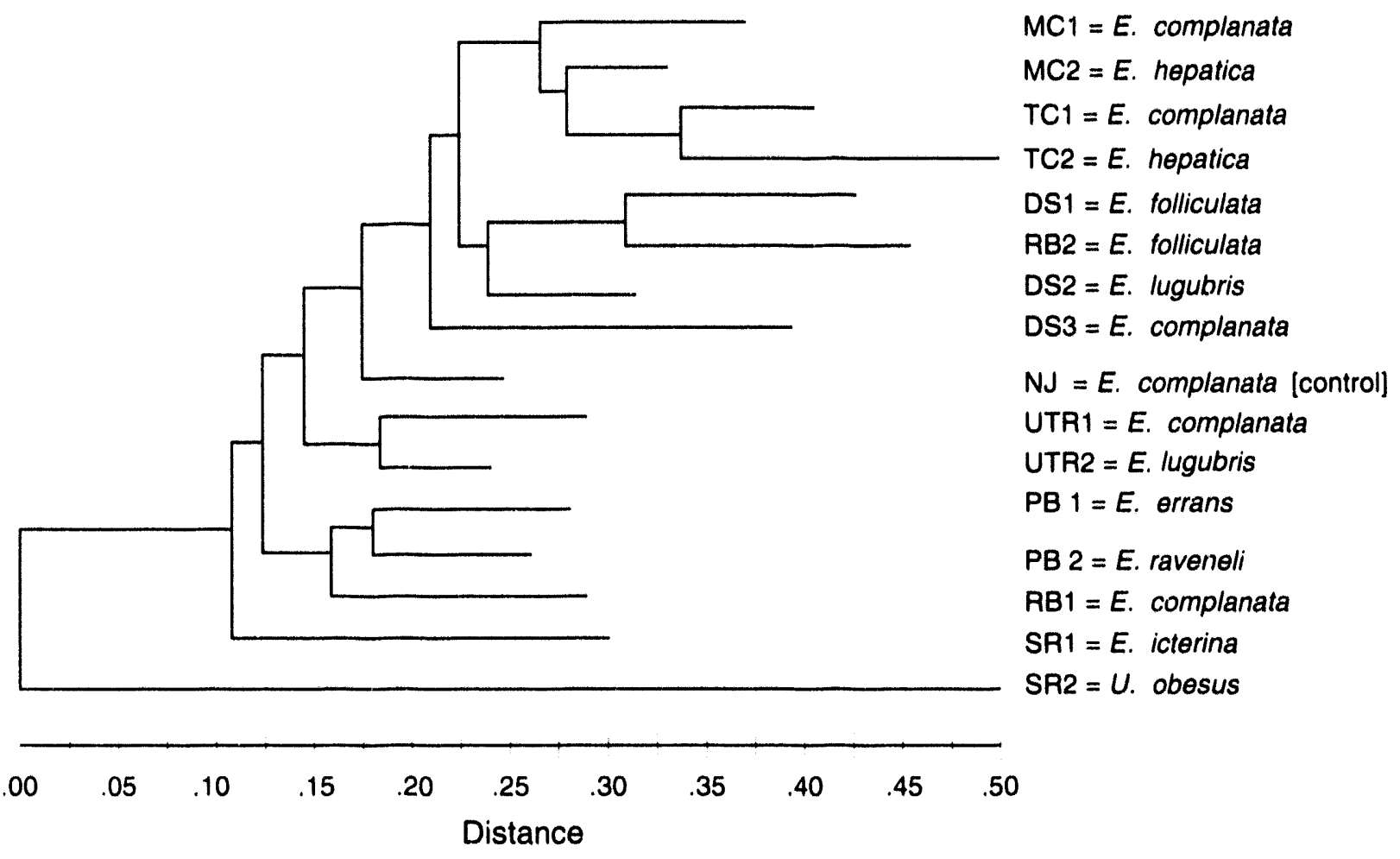

Figure 6. Wagner tree based on electrophoretic data. 


\section{${ }^{1.9}$ Multidimensional scaling Factors I x II; with minimum spanning tree}

E. icterina

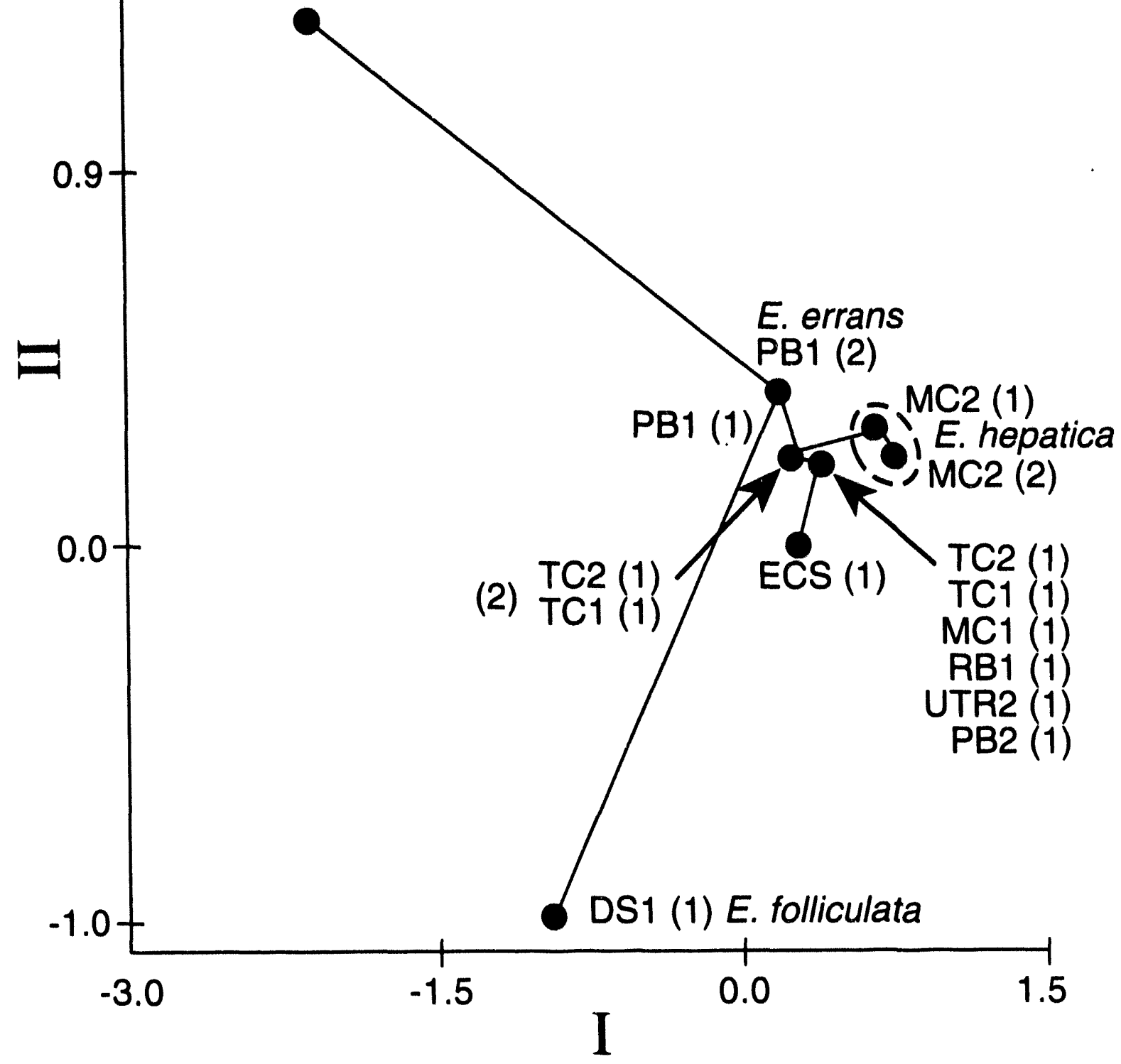

Figure 7. Ordination of qualitative data I x II. 


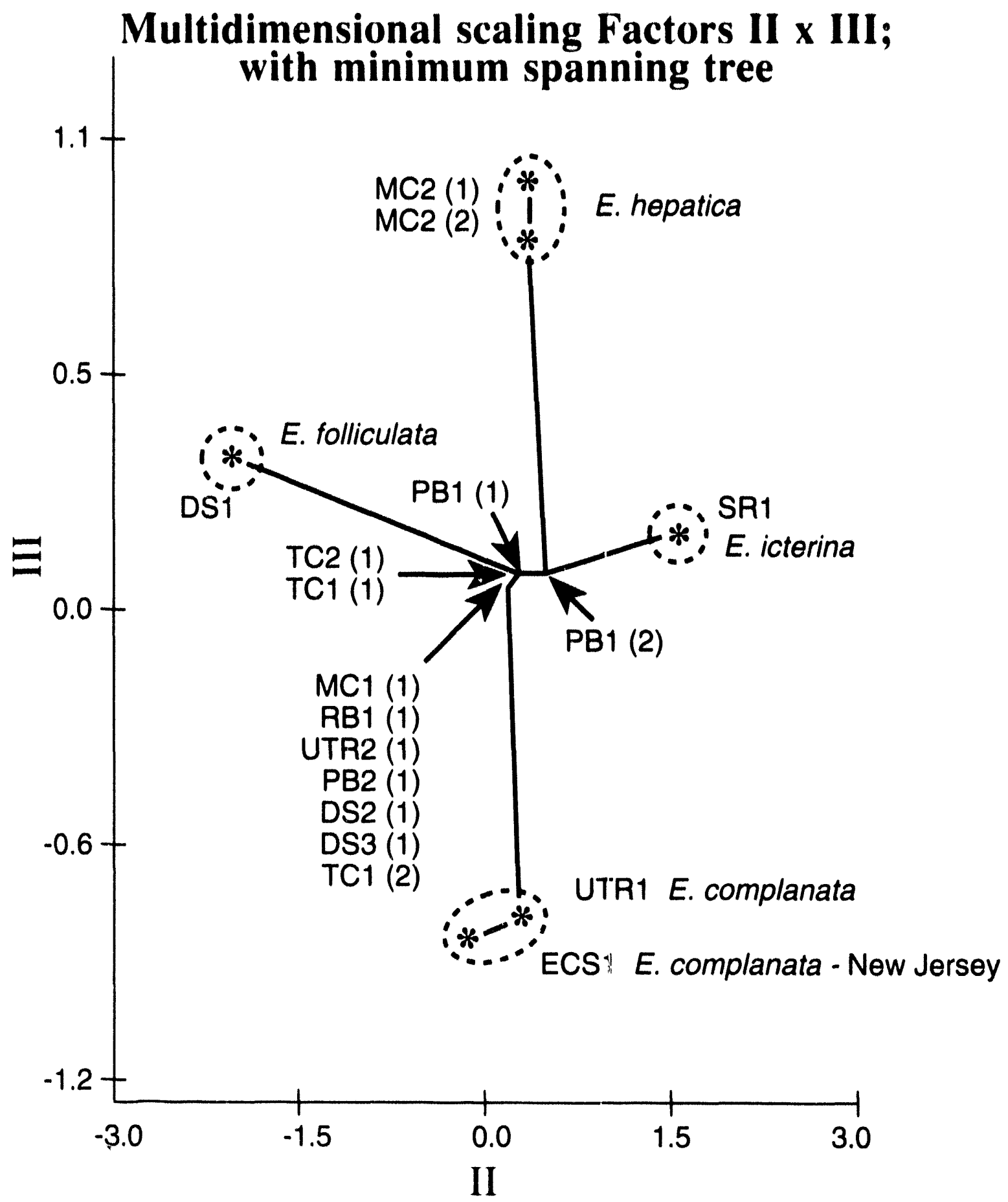

Figure 8. Ordination of qualitative data II x III. 


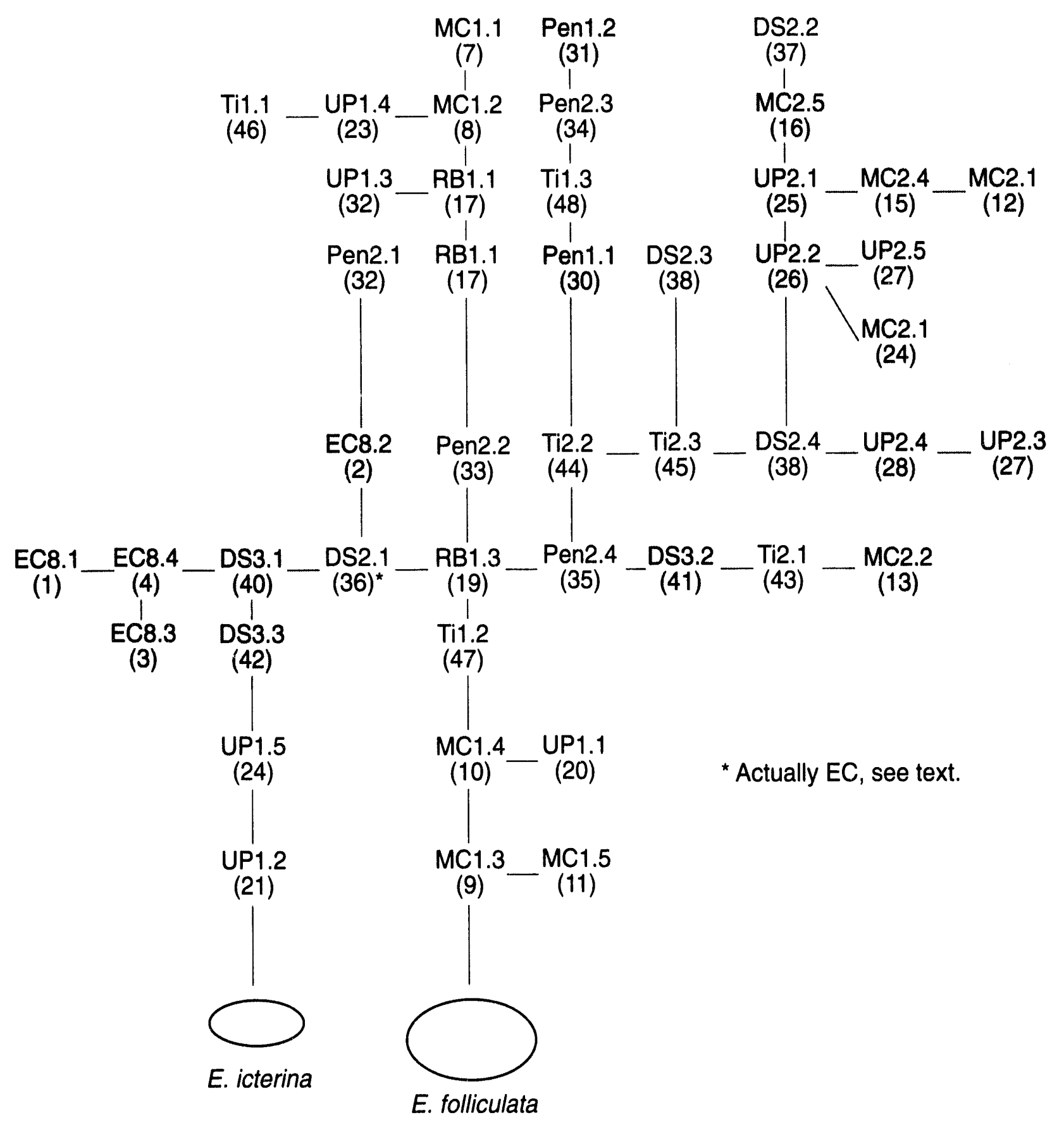

Figure 9. Minimum spanning tree for quantitative data by individual and location designation. 


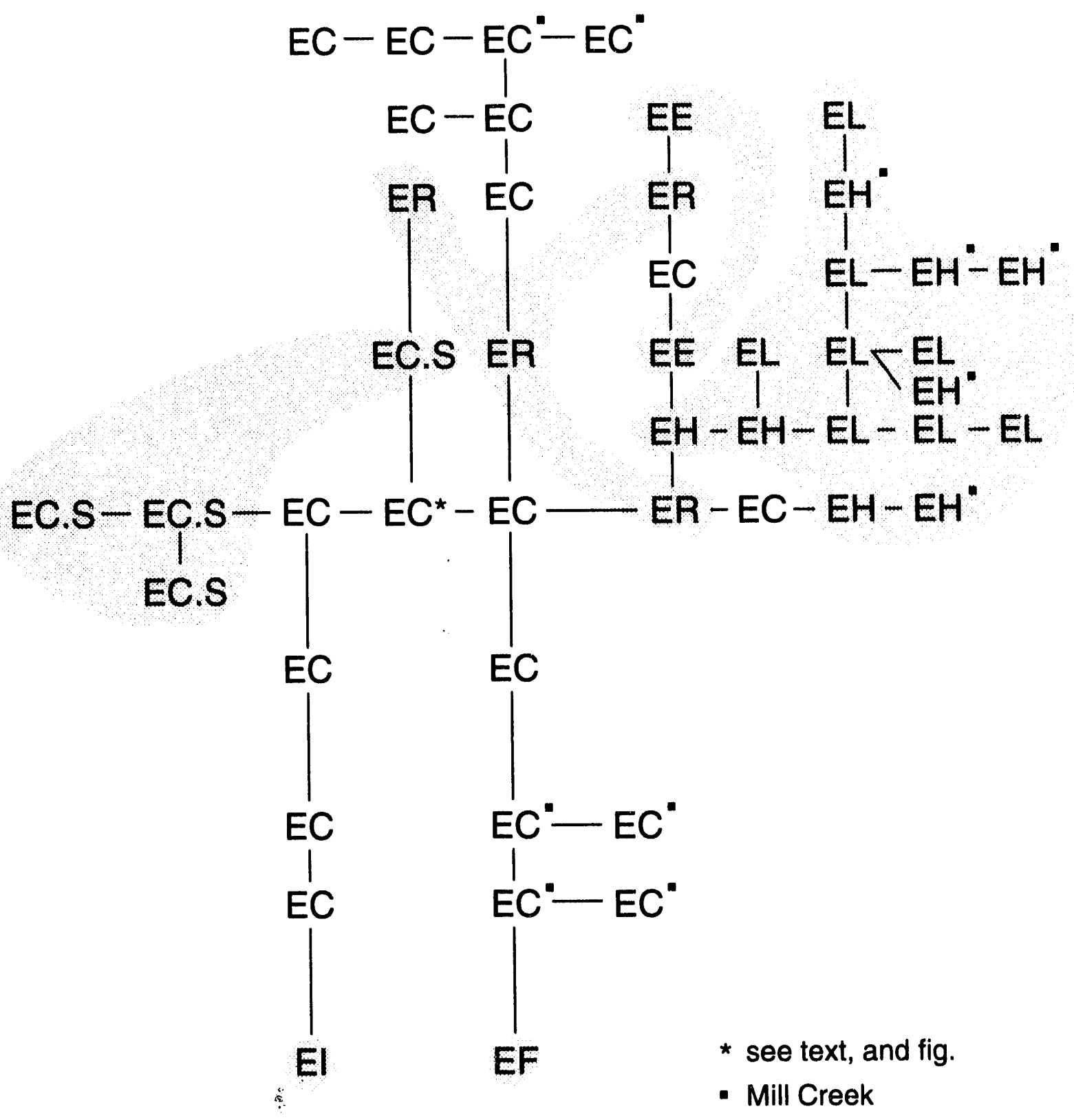

Figure 10. Minimum spanning tree by species names. 


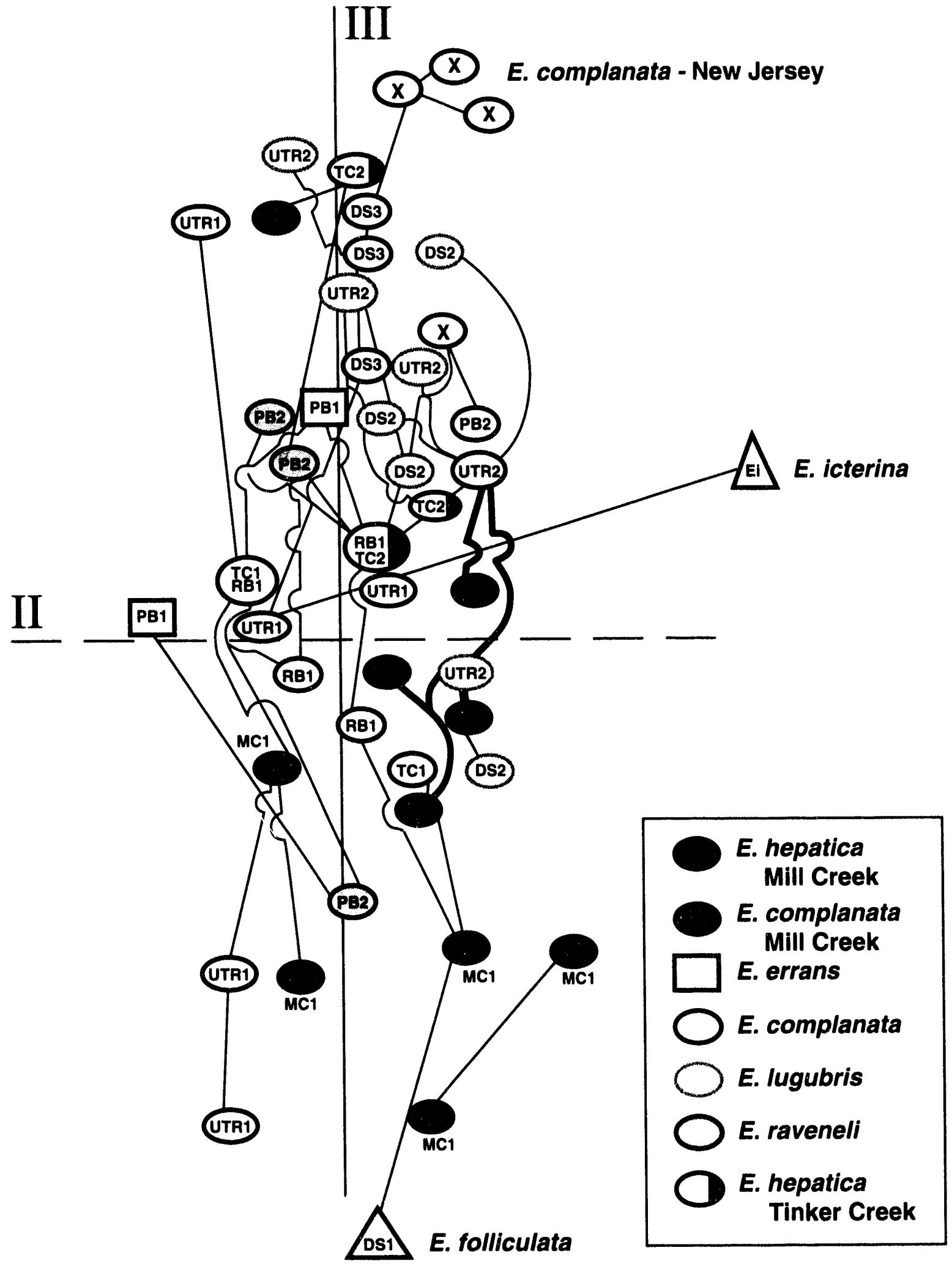

Figure 11. Ordination of quantitative data. 


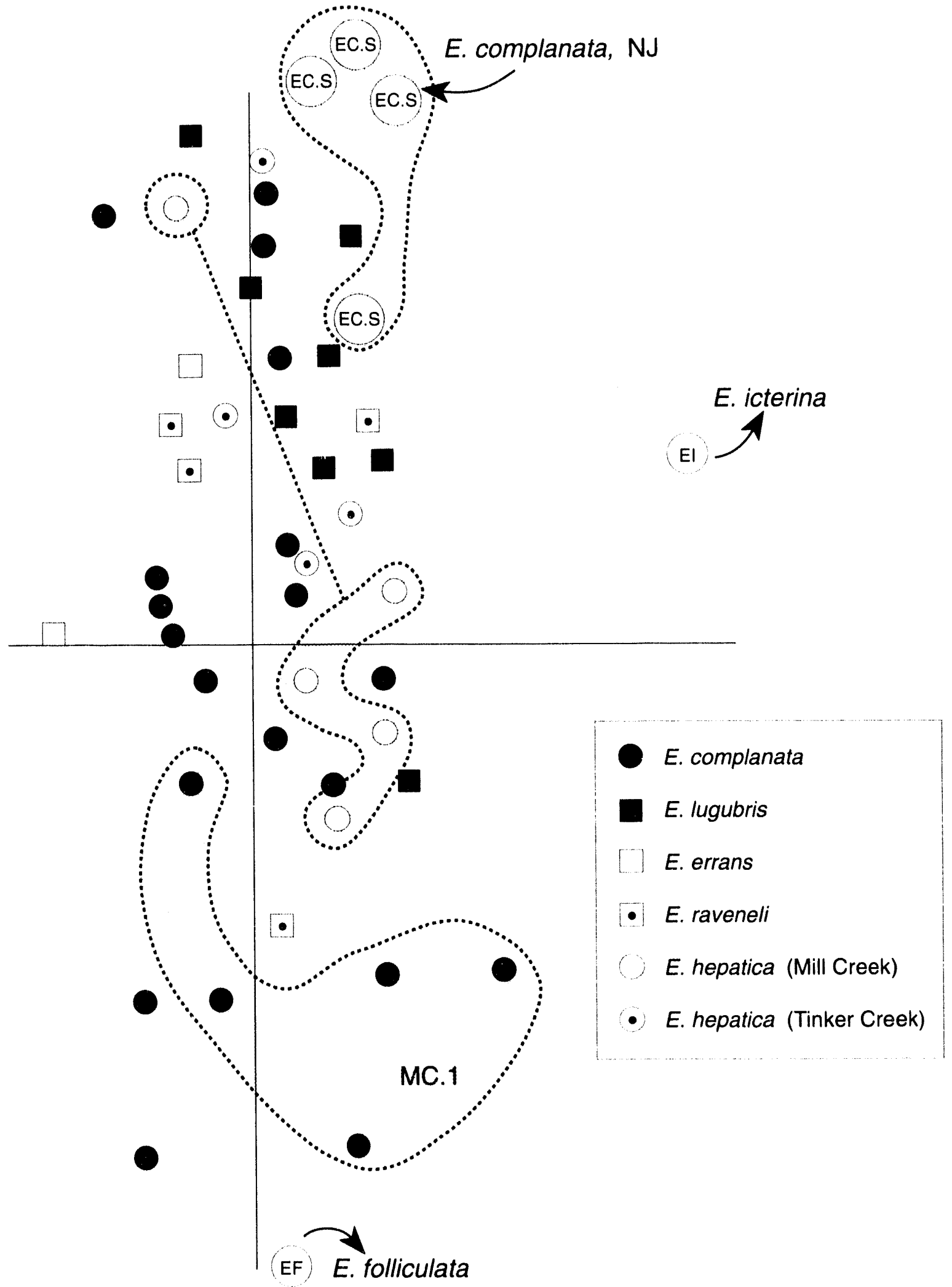

Figure 12. Ordination of quantitative data, remove MST, circle grows. 


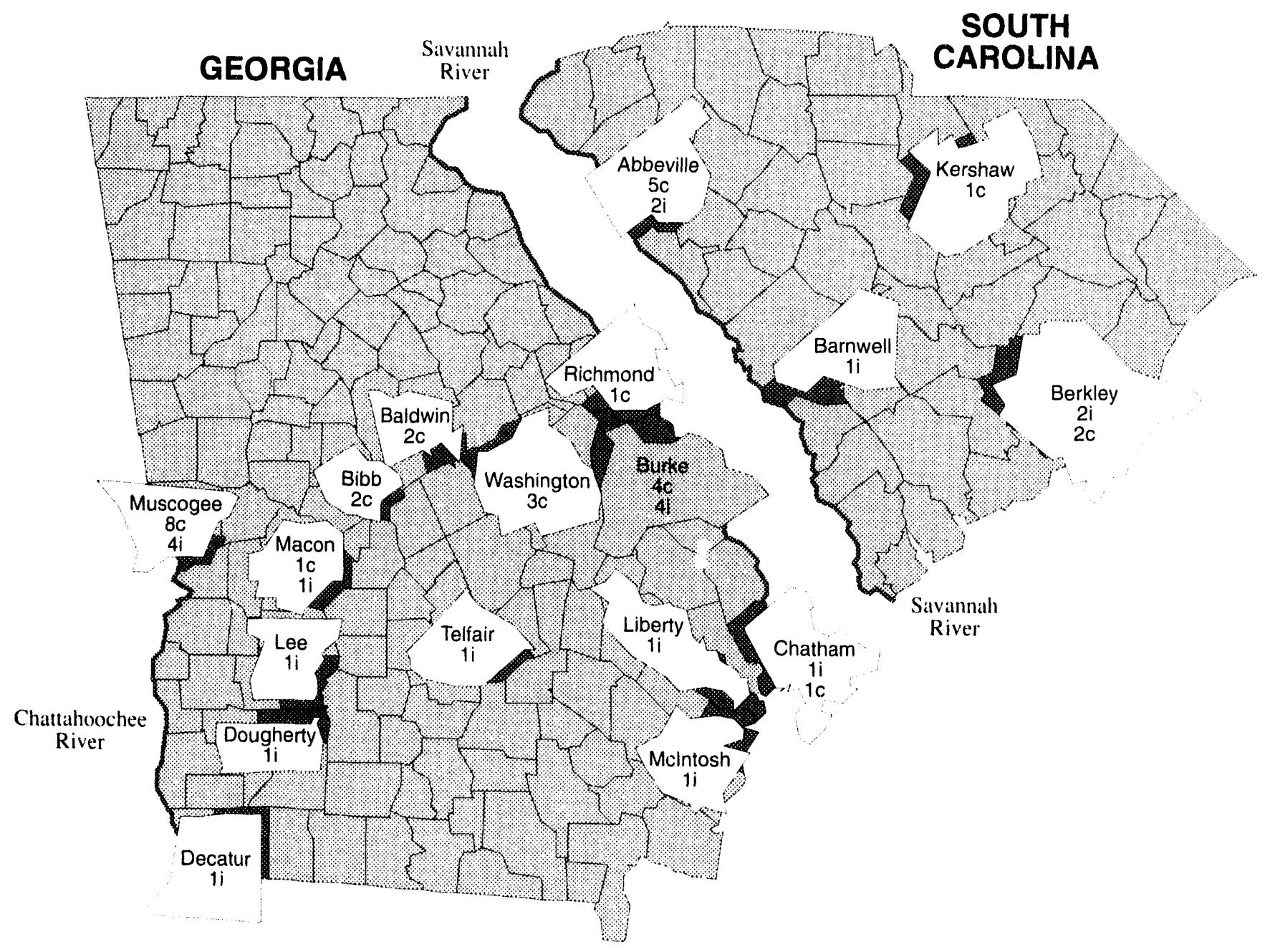

Fig. 13. Distribution of nominal species placed into the synonymy of $E$. complanata (c) or $E$. icterina (i) from Georgia and South Carolina. 
E. complanata

A E. errans

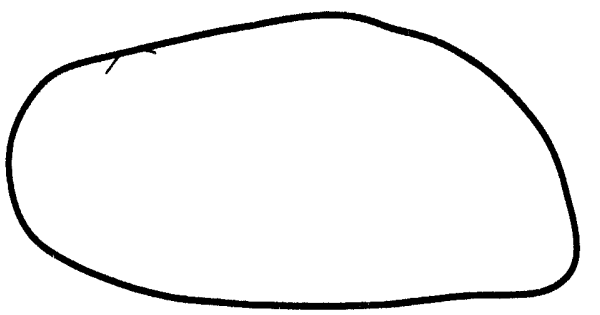

B E. hepatica

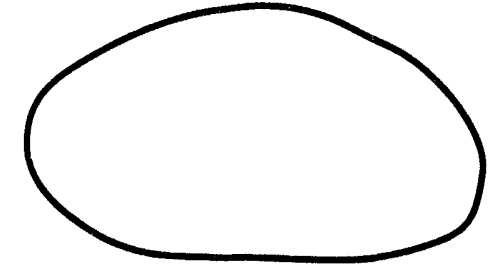

C E. merceri

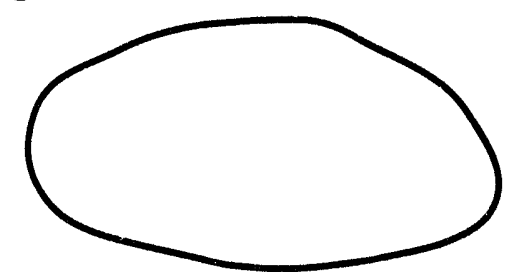

D E. lugubris

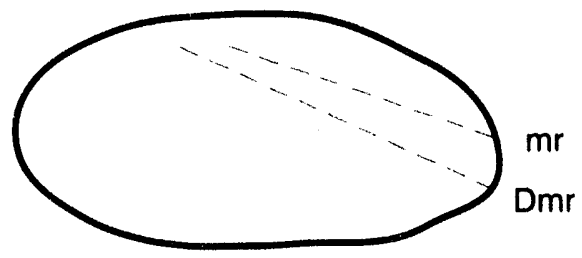

$E$

E. raveneli

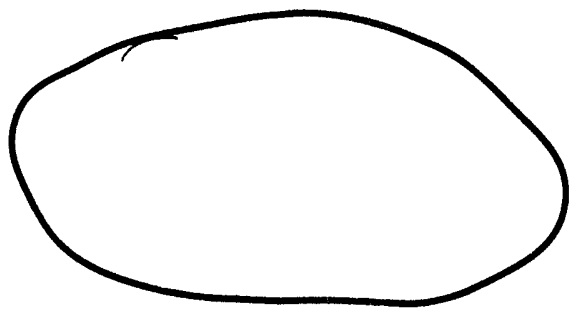

F Philadelphia, PA

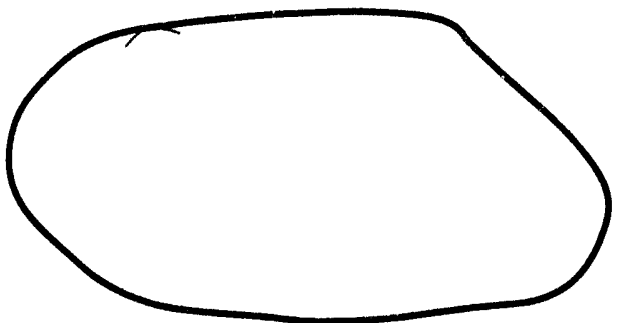

G Washington, DC

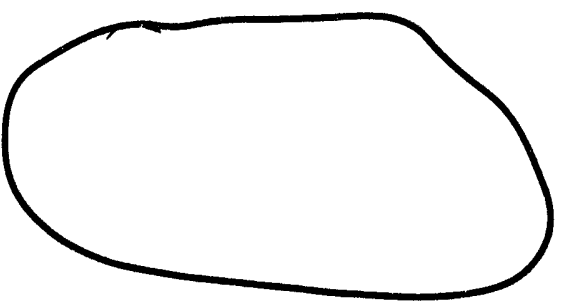

H Mattaponi River

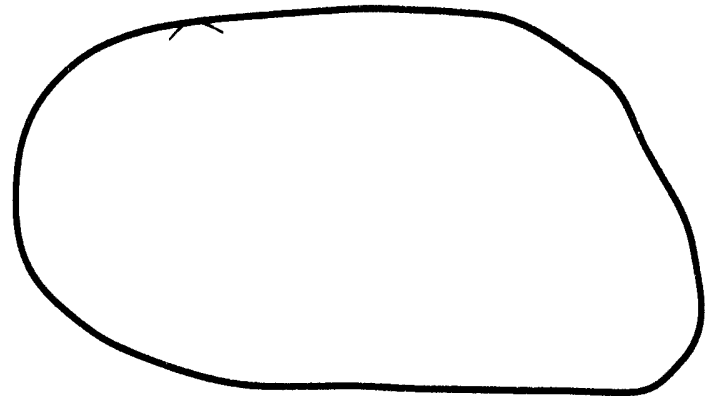

I James River

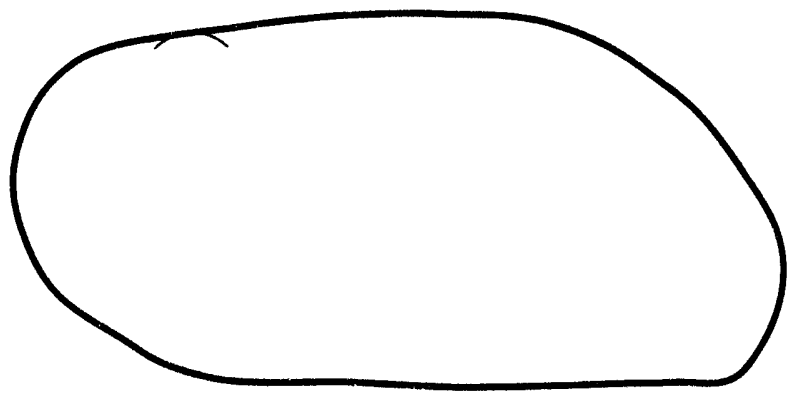

Fig. 14. Shell shapes from tracings of shells. A-D are holotypes. A. Elliptio errans, B. E. hepatica, C. E. merceri, D. E. lugubris, E. E. raveneli from this study. F- $\mathrm{H}$ are E. complanata F. from Schuylkill River, Philadelphia, PA; NMNH 85478. G. Washington, D.C. Potomac River? topotype? NMNH 25194. H. Mattaponi River, Virginia, NMNH. I. James River, Virginia, NMNH 837318. 

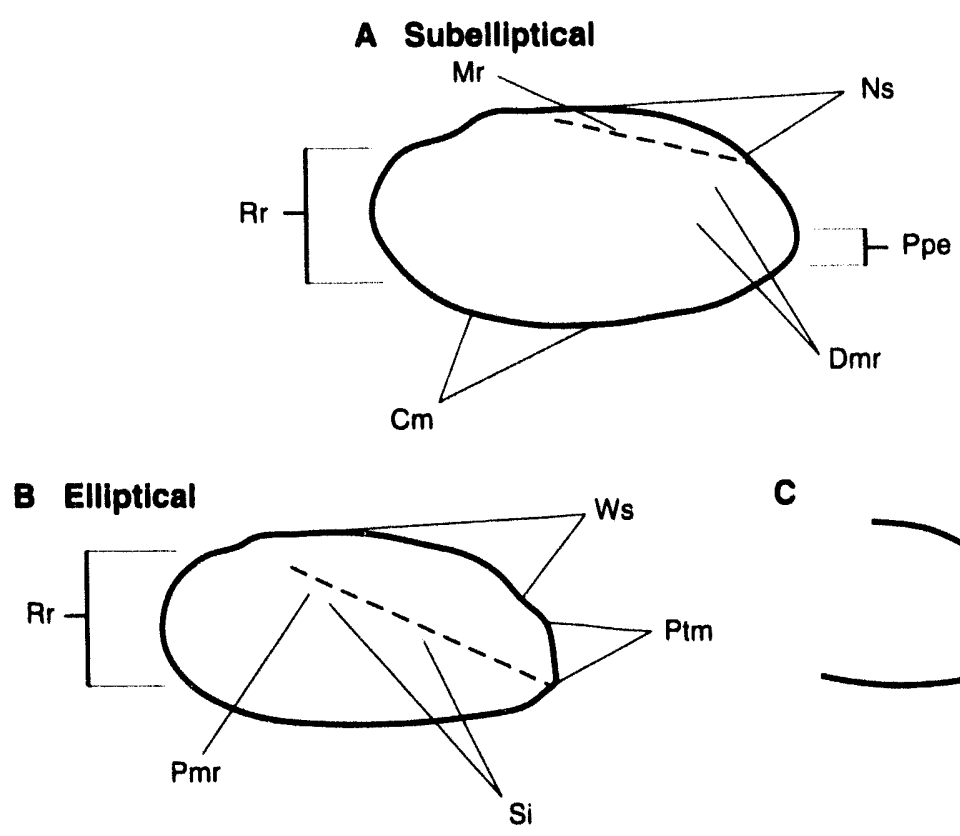

C
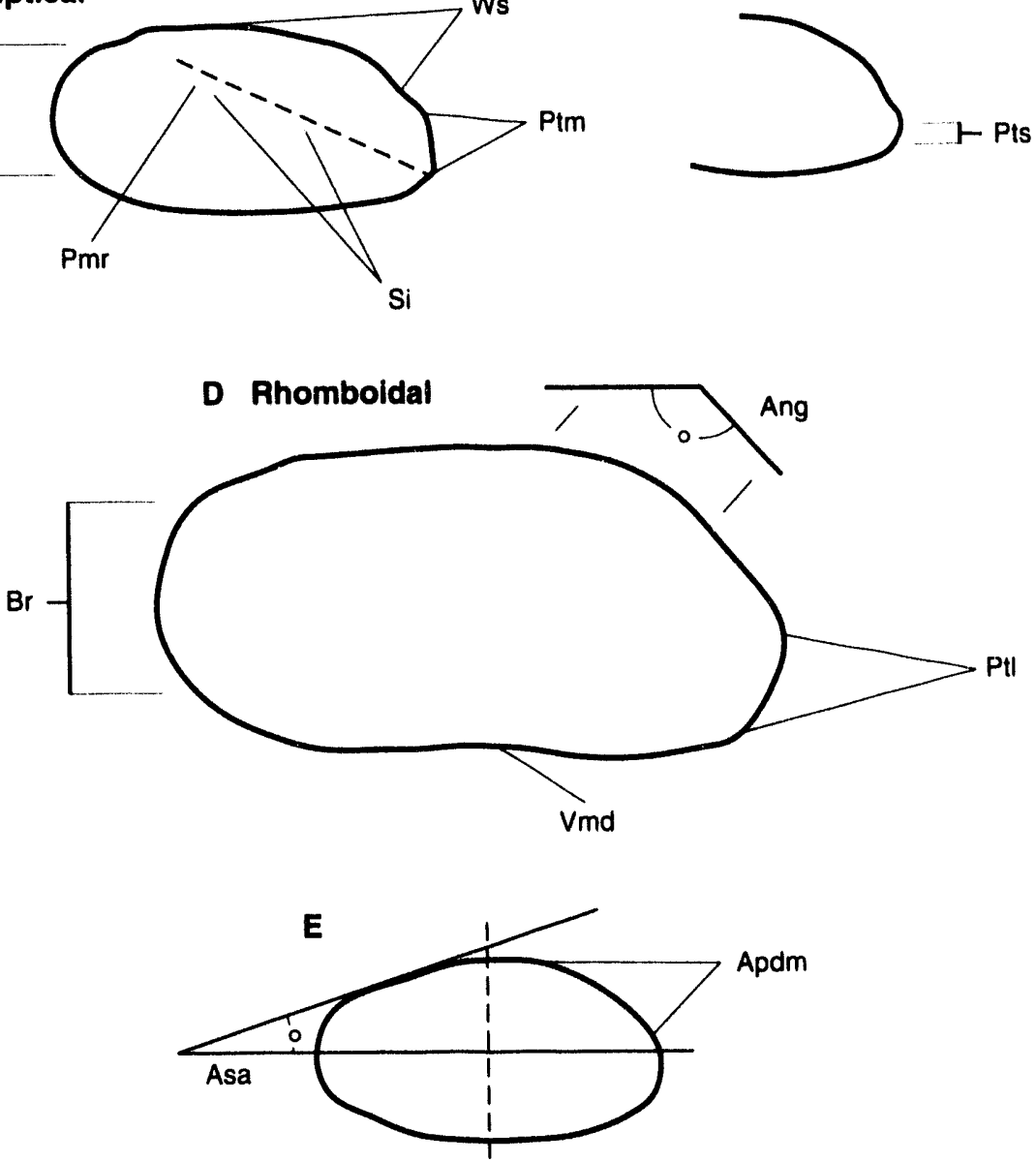

Fig. 15. Shell shapes and characters. A. Elliptio icterina from this study. B. E. lugubris type; C. Posterior end of E. icterina; D. E. complanata this study; E. E. hepatica, this study.

Abbreviations are as follows: Posterior margin with angulation (Ang), Arcuate posterior dorsal margin (Apdm),Anterior slope angle (Asa), Blunt, flattened curve of anterior end $(\mathrm{Br})$, Convex ventral margin $(\mathrm{Cm})$, Doubled major ridge $(\mathrm{Dmr})$, Minor ridge $(\mathrm{Mr})$, Narrow shelf (Ns), Pointed posterior end (Ppe), Position of major ridge (Pmr), Posterior truncation long (Ptl), Posterior truncation medium length (Ptm), Posterior truncation short (Pts), Regularly rounded anterior end (Rr), Strongly inflated along posterior ridge (Si), Ventral margin depression (Vmd), Wide shelf (Ws) 

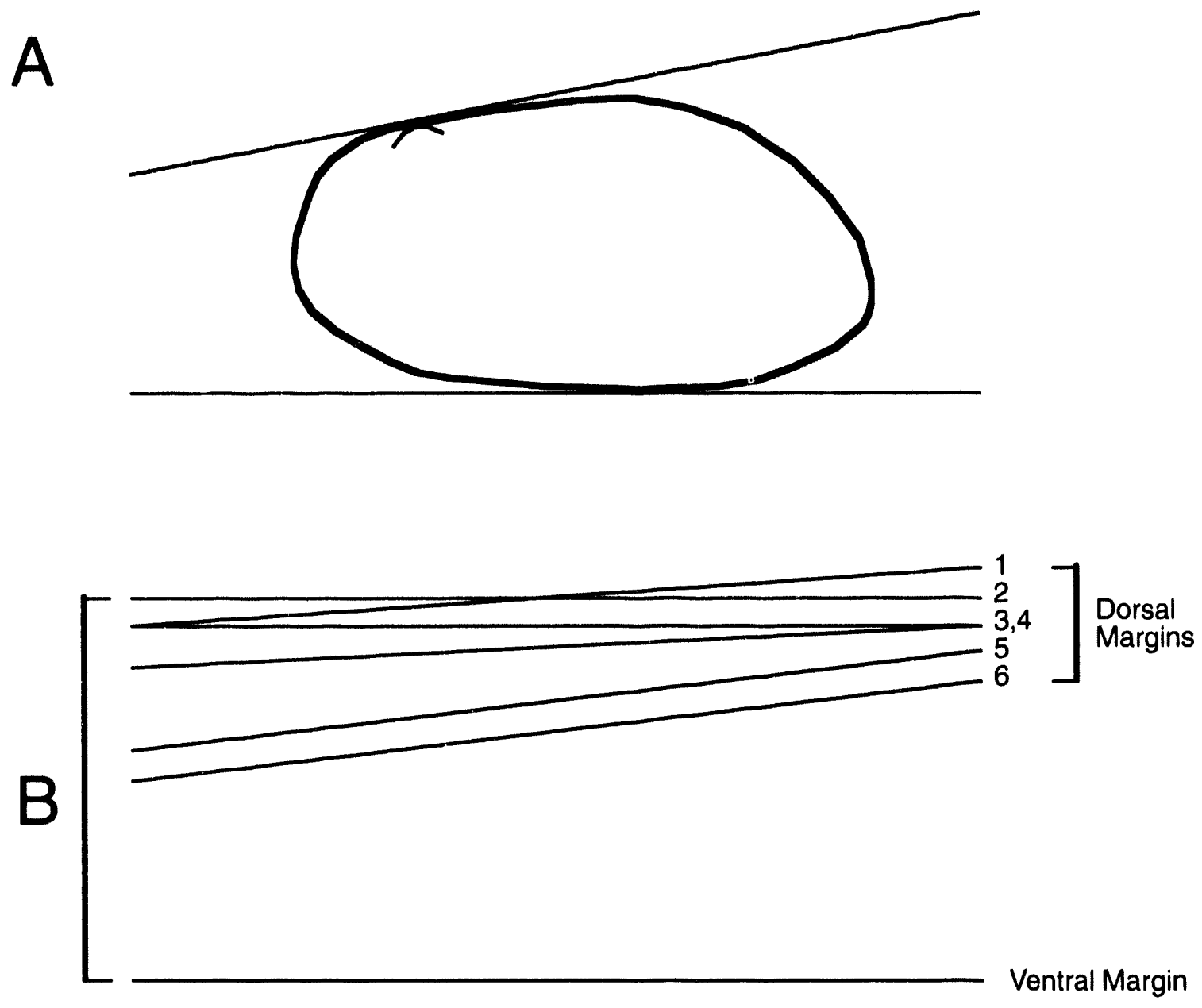

Fig. 16. Dorsal and ventral margins as they depart from being parallel. A. Type of E. errans; moderate dorsal margin angle in all specimens. B. Dorsal margins of six individuals of different populations of $E$. complanata. Individuals $1-4$ have dorsal margins nearly parallel to the ventral margin; individuals 5 and 6 have a dorsal margin angle similar to that of $E$. errans. 

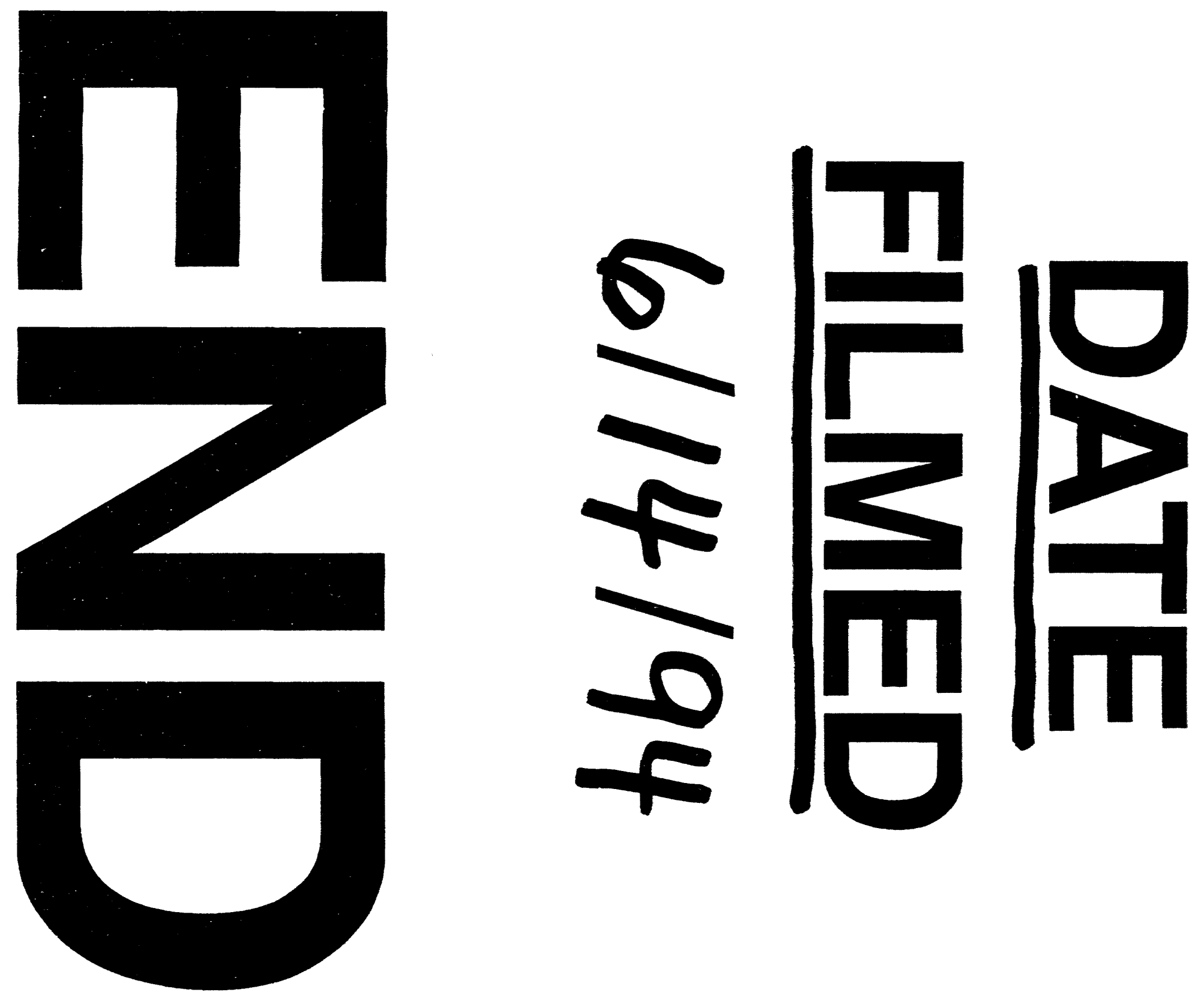
